\title{
42. X-RAY MINERALOGY STUDIES, LEG 41, DEEP SEA DRILLING PROJECT, EASTERN NORTH ATLANTIC OCEAN
}

\author{
Fréderic Mélières, Université Pierre et Marie Curie, Paris, France
}

\section{INTRODUCTION}

This report synthesizes X-ray mineralogy data from Sites $366,367,368,369$, and 370 , where deep holes were drilled and frequently continuously cored, during Leg 41 on the northwestern African Margin (Figure 1). Two hundred and seventy samples (one per core) were submitted for X-ray diffraction analysis. In a few cases several samples were taken in contrasting lithologies within the same core. But, with the exception of these zones, the knowledge of the mineralogical facies results from a large-scale sampling which allows a discussion of only the major features of the sedimentary column.

\section{ANALYTICAL PROCEDURES}

A detailed study of the clay mineralogy on a carbonate-free fraction was not carried out because carbonate-rich lithologies were frequently encountered, and because of the small size of the samples $(3 \mathrm{cc})$. Therefore, the clay minerals were analyzed without grain-size consideration and they appear as common constituents of the mineralogical spectrum.

The analytical procedure used, basically operating on non-oriented powder with the use of an internal standard for quantitative determinations, is described elsewhere (Mélières, 1974). A summary of the basic steps is as follows.

The samples were manually ground in an agate mortar, without any pretreatment. After oven drying at $40^{\circ} \mathrm{C}, 50 \mathrm{mg}$ of internal standard (sodium fluoride) were mixed with $250 \mathrm{mg}$ of sediment by grinding in the mortar. The mixture was then mounted in a rotating sample holder (Mélières, 1973) with a speed of 10 $\mathrm{rev} / \mathrm{sec}$ to insure good reproducibility of the diffracted peak intensities. A Siemens diffractometer, equipped with a fine-focus copper tube, was used to run the Xray diffraction scans. $\mathrm{CuK} \alpha$ radiation was isolated by a nickel filter. The geometry of the X-ray beam was determined by a $0.5^{\circ}$ entering slit, a $0.2 \mathrm{~mm}$ receiving slit, and a frontal knife. The X-ray source intensity was set in order to obtain all the peaks of the constituents (including the internal standard, but excepting the clay minerals), in the best recording conditions. The first scan was then recorded $\left(15^{\circ}\right.$ to $\left.45^{\circ} 2 \theta\right)$ at $1^{\circ} 2 \theta / \mathrm{min}$. A second scan was run for clay minerals $\left(2^{\circ}\right.$ to $\left.17^{\circ} 2 \theta\right)$ under the same conditions but with appropriate gain, depending on the abundance of these minerals in the sample. The third scan was a slow scan $\left(0.5^{\circ} 2 \theta\right.$ /min or less) resolving the doublet kaolinite(002)/chlorite(004) $\left(24^{\circ}\right.$ to $\left.26^{\circ} 2 \theta\right)$. After the sample, in its holder, was exposed to a current of ethylene-glycol for five minutes to expand the smectite minerals, a fourth scan (with the same conditions as the second one) was run.

The identification of minerals was carried out by reference to standard diffractograms made in the

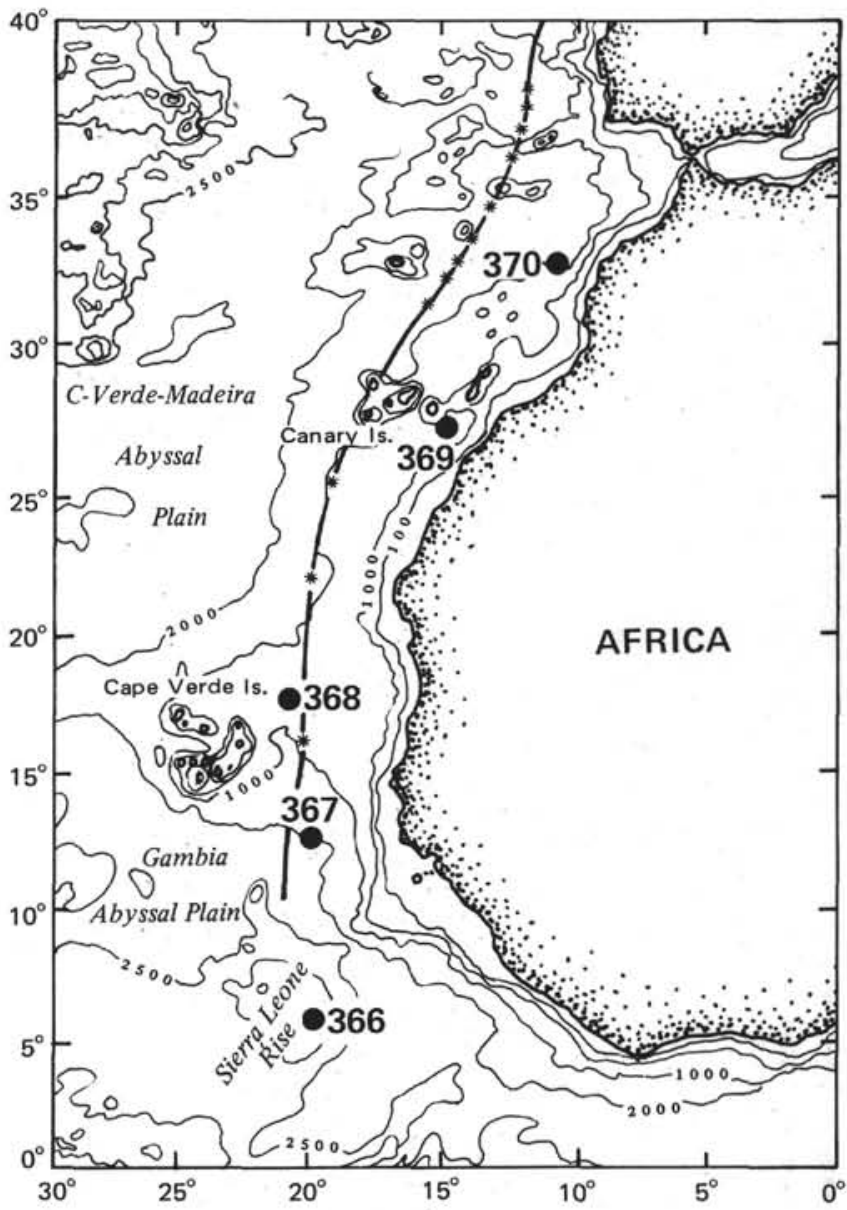

Figure 1. Location of Leg 41 drill sites.

laboratory on pure natural constituents, and, when necessary, with ASTM data and classical handbooks (Brown, 1963; Borg and Smith, 1969).

The quantitative analysis was carried out using calibrated curves giving the mass ratio (given mineral versus internal standard) from the peak intensities ratio. All these curves were prepared in the laboratory, using the classical procedure of artificial mixtures (Klug and Alexander, 1967). Two kinds of measurement of peak intensities are used, depending on minerals: (1) for minerals well crystallized but offering various degrees of crystallinity (quartz, carbonates, etc.), both peak height and width at half-height were used (two entries in the calibrated curve); and (2) for minerals more or less well crystallized (clay minerals, opal-CT, etc.), the weighted peak area above the background was used. The precisions of the quantitative estimates range from $5 \%$ to $15 \%$ relative, and depend mainly on the nature of the mineral. Percentages are given in integer numbers, the first decimal being deleted 
except for values below $10 \%$. Amounts of mineral below $0.2 \%$ are referred to as traces (T) on Tables 1 to 7.

\section{COMMENTS ON MINERALOGICAL DATA}

The purpose of these comments is to contribute to a better understanding of the data given in Tables 1 to 7 , as well as an easier reading of the mineralogical logs (Figures 2 to 6).

\section{Quartz}

The quantitative estimates were made using both (100) and (101) peaks. The crystallinity was estimated from the width at half-height of (101) peak (L 1/2 [101] in data tables and figures), measured by means of a micrometer; the value is given in $1 / 10^{\circ} 2 \theta$, and the degree of precision is: $\pm 0.01^{\circ} 2 \theta$. Corrections were made for the influence of foreign peaks ([003] illite, $\mathrm{K} \beta[104]$ calcite). Quartz, usually present in terrigenous detrital material was always characterized by a high degree of crystallinity $(\mathrm{L} \mathrm{I} / 2=1.7 \pm 0.1)$; authigenic quartz, which occurs mainly in cherts as chalcedony, is characterized by a much lower degree of crystallinity (L $1 / 2$ values reach 3.5 ).

\section{Opal-CT}

The nomenclature used here follows the definition given by Jones and Segnit (1971). The heights of the "cristobalite" peak $\left(21.6^{\circ} 2 \theta\right)$ and the "tridymite" peak $\left(20.6^{\circ} 2 \theta\right)$ above the background are labeled, respectively, $\mathrm{A}$ and $\mathrm{B}$, and the $\mathrm{B} / \mathrm{A}$ ratio, appearing in data tables and figures, is tentatively used here to characterize the mineral. The abundance of opal-CT was estimated from the area of the wide "peak" $\left(19^{\circ}\right.$ to $24^{\circ} 2 \theta$ ) above the background, corrected for the influence of foreign minerals.

\section{Clinoptilolite}

A considerable variation of relative intensities of the (200) and (020) peaks for clinoptilolite was noted from sample to sample. This observation was pointed out by von Rad and Rösch (1972) at Site 144 (Demerara Rise, western central Atlantic, Leg 14). Unfortunately, the data given by these authors are very difficult to interpret because of a misprinting (Figure 5, ref. cit.). The $(200) /(020)$ peak to height ratio in "normal" clinoptilolite (Mumpton, 1960) has a value close to 0.4; this type occurs in Leg 41 sediments at Sites 369 and 370 . The (200) peak at $11.2^{\circ} 2 \theta$ in "atypical" clinoptilolite is abnormally intense with regard to the (020) peak at $9.8^{\circ} 2 \theta$, yielding $(200) /(020)$ ratios reaching 5; this type occurs commonly in Leg 41 sediments at all sites but 368 . Von Rad and Rösch (1972) tentatively explain the difference in peak intensities as isomorphous substitution. Although it is not impossible that such a substitution could enhance the (200) peak by raising the structure factor of (200) reticular planes, the $(200)$ peak enhancement may also be due to a preferential development of (200) crystal faces in particular conditions of growth. This latter explanation seems to be supported by the fact that the "atypical" clinoptilolite occurs frequently above (in the sedimentary column) the normal type (namely at Site 369). Further investigation by means of SEM and XRD will certainly bring some light on this critical point. The $(200) /(020)$ peak height ratio for this study was measured as frequently as possible and appears in data tables and figures.

\section{Calcite}

The $\mathrm{MgCO}_{3}$ content (mole), measured according to Vegard's law (Goldsmith and Graf, 1958), is always very low and ranges from 0 to $1 \%$ and therefore is not reported in the data tables. Generally speaking, the crystallinity, estimated from the width at half-height of (104) peak, is rather constant, and no significant variations occur in routine measurements $\left(1^{\circ} 2 \theta / \mathrm{min}\right)$. However, special attention was paid to the calcite crystallinity at Site 366. An extremely reduced contribution of detrital terrigenous input can reasonably be expected because of the physiographic position of this site on the Sierra Leone Rise (see Site Chapter). Therefore, calcite at this site is thought to be exclusively of biogenic origin. A very careful measurement of the crystallinity was carried out, using five repeated scans of the (104) calcite peak at very slow speed $\left(0.25^{\circ} 2 \theta / \mathrm{min}\right)$, on each sample. The precision of the measurement $( \pm 2 \%)$ allows the identification of variations of the calcite crystallinity, which will be discussed later. The values are listed in Tables 1 and 2 in the column "calcite L 1/2 (104)," and in Figure 2.

\section{Dolomite}

As far as possible, the distinction between stoichiometric and calcic dolomites (respectively, labeled "s" and " $\mathrm{c}$ " in the data tables and in the figures) was made from the shape of the (104) peak. The (104) peak of stoichiometric dolomite occurs at $30.98^{\circ} 2 \theta$, and the (104) peak of calcic dolomite occurs at lower angles, depending on the calcium content (Vegar's law). Aside from the percentages given (total amount of dolomite(s) in the sample), data on the nature of this mineral are reported in the column "nature" (data tables and figures), where the numbers indicate the calcium content of the calcic dolomite. The rough relative proportions of stoichiometric "s" and calcic "c" dolomites in a same sample are indicated in the data tables by means of the following scale:

$$
\begin{aligned}
& \mathrm{s}=\text { stoichiometric dolomite } \\
& \mathrm{s} / \mathrm{c}=\text { "s" largely dominant } \\
& \mathrm{s}+\mathrm{c}=\text { "s" slightly dominant } \\
& \mathrm{c}+\mathrm{s}=\text { "c" slightly dominant } \\
& \mathrm{c} / \mathrm{s}=\text { "c" largely dominant } \\
& \mathrm{c}=\text { calcic dolomite }
\end{aligned}
$$

\section{Halite}

A small peak of halite occurs very frequently in the diffractograms because of the procedure used in the sample preparation prior to diffraction (see analytical procedures above). This halite does not exist in the sediment as a mineral, but results from the evaporation of the interstitial water when the samples are ovendried. Nevertheless, the amount of this "halite" in the samples is reported for two reasons: (1) from an analytical point of view (quantitative estimation), this halite constitutes a part of the mass of the sample, and it is necessary to add it to the other crystallized constituents in order to obtain the total crystallized 
TABLE 1

Bulk X-Ray Mineralogy Data, Site 366, Hole 366

\begin{tabular}{|c|c|c|c|c|c|c|c|c|c|c|c|c|c|c|c|c|c|c|}
\hline \multirow[b]{2}{*}{$\begin{array}{c}\text { Sample } \\
\text { (Interval in } \mathrm{cm} \text { ) }\end{array}$} & \multicolumn{2}{|c|}{ Quartz } & \multicolumn{2}{|c|}{ Feldspar } & \multicolumn{2}{|c|}{ Opal-CT } & \multicolumn{2}{|c|}{ Clinoptilolite } & \multicolumn{2}{|c|}{ Calcite } & \multirow[t]{2}{*}{ Halite } & \multirow[t]{2}{*}{ Illite } & \multirow{2}{*}{$\begin{array}{l}\text { Mixed } \\
\text { Layer }\end{array}$} & \multirow{2}{*}{$\begin{array}{l}\text { Smec- } \\
\text { tite }\end{array}$} & \multirow{2}{*}{$\begin{array}{l}\text { Atta- } \\
\text { pulgite }\end{array}$} & \multirow{2}{*}{$\begin{array}{l}\text { Kaoli- } \\
\text { nite }\end{array}$} & \multirow[b]{2}{*}{ Total } & \multirow{2}{*}{$\begin{array}{l}\text { Amorph. } \\
\text { Material }\end{array}$} \\
\hline & $\%$ & $\begin{array}{r}\mathrm{L}^{1 / 2} \\
(101)\end{array}$ & Plag. & K & $\%$ & $\begin{array}{l}\mathrm{B} \\
\mathrm{A}\end{array}$ & $\%$ & $\frac{(200)}{(010)}$ & $\%$ & $\begin{array}{l}L 1 / 2 \\
(104)\end{array}$ & & & & & & & & \\
\hline $1-2,6-7$ & 3.0 & 1.7 & - & - & - & & - & & 53 & 1.72 & 2 & 1.8 & 1.0 & 2.2 & - & 4.2 & 68 & 32 \\
\hline $2-2,19-20$ & 7.1 & 1.8 & $\mathrm{~T}$ & I & - & & - & & 29 & 1.65 & 1.8 & 4.8 & 2.0 & 6.3 & - & 7.3 & 60 & 40 \\
\hline $3-5,75-76$ & 6.0 & 1.7 & - & $\mathrm{T}$ & - & & - & & 32 & 1.60 & 0.4 & 1.2 & 3.3 & 2.8 & - & 14 & 60 & 40 \\
\hline $4-2,134-135$ & 0.8 & & - & $\mathrm{T}$ & - & & - & & 76 & 1.55 & 1.2 & - & - & 1.3 & - & 1.6 & 81 & 19 \\
\hline $5-2,3-5$ & 0.5 & & - & - & - & & 2.8 & 5 & 69 & 1.57 & 0.7 & - & - & $\mathrm{T}$ & - & $\mathrm{T}$ & 73 & 27 \\
\hline $6-3,64-65$ & - & & - & - & - & & - & & 75 & 1.62 & 1.1 & - & - & 3.1 & - & - & 80 & 20 \\
\hline $7-3,70-71$ & 0.4 & & - & - & - & & - & & 73 & 1.57 & 1.0 & - & - & 4.1 & - & - & 79 & 21 \\
\hline $9-3,59-60$ & - & & - & - & - & & - & & 76 & 1.62 & 0.4 & - & - & 4.9 & - & - & 82 & 18 \\
\hline $10-2,57-58$ & 0.4 & & - & - & - & & - & & 70 & 1.55 & 0.7 & - & - & 3.9 & - & - & 75 & 25 \\
\hline $11-1,49-50$ & - & & - & - & - & & - & & 69 & 1.52 & 0.9 & - & - & 4.8 & - & - & 75 & 25 \\
\hline $12-3,75-76$ & - & & - & - & - & & - & & 62 & 1.50 & 0.5 & - & - & 10.5 & - & - & 73 & 27 \\
\hline $13-2,81-82$ & $\mathrm{~T}$ & & - & - & - & & - & & 56 & 1.52 & 0.6 & - & - & 8.8 & - & - & 66 & 34 \\
\hline $14-3,84-85$ & - & & - & - & 3.0 & & - & & 54 & 1.55 & 1.3 & - & - & 5.8 & - & - & 64 & 36 \\
\hline $15-1,54-55$ & - & & - & - & - & & - & & 76 & 1.52 & 0.5 & - & - & 3.3 & - & - & 80 & 20 \\
\hline $16-2,8-9$ & $\mathrm{~T}$ & & - & - & - & & - & & 65 & 1.47 & 0.4 & - & - & 8.4 & - & - & 74 & 26 \\
\hline $19-1,102-103$ & $\mathrm{~T}$ & & - & - & $\mathrm{T}$ & & - & & 75 & 1.55 & 0.5 & - & - & 4.7 & - & - & 80 & 20 \\
\hline $20-2,131-132$ & - & & - & - & 8.1 & 0.60 & - & & 74 & 1.65 & 0.4 & - & - & 5.0 & - & - & 87 & 13 \\
\hline $21-2,82-83$ & - & & - & - & 2.3 & & - & & 82 & 1.60 & 0.4 & - & - & 3.3 & - & - & 88 & 12 \\
\hline $22-1,50-51$ & - & & - & - & 5.6 & 0.60 & - & & 80 & 1.58 & 0.4 & - & - & 3.3 & - & - & 90 & 10 \\
\hline $23-1,69-70$ & - & & - & - & 3.2 & & - & & 88 & 1.62 & 0.4 & - & - & 2.7 & - & - & 95 & 5 \\
\hline $24-2,111-112$ & - & & - & - & 6.3 & & - & & 82 & 1.58 & 0.3 & - & - & 5.1 & - & - & 94 & 6 \\
\hline $25-2,59-60$ & 19 & 2.9 & - & - & 46 & 0.50 & - & & 31 & 1.70 & - & - & - & $\mathrm{T}$ & - & - & 96 & 4 \\
\hline $27-2,79-80$ & - & & - & - & 14 & 0.47 & - & & 70 & 1.68 & - & - & - & 1.8 & - & - & 86 & 14 \\
\hline $28-3,58-59$ & - & & - & - & 18 & 0.46 & - & & 72 & 1.67 & $\mathrm{~T}$ & - & - & 2.7 & - & - & 92 & 8 \\
\hline $29-2,37-38$ & 1.2 & 2.8 & - & - & 9.6 & 0.45 & - & & 65 & 1.63 & $\mathrm{~T}$ & - & - & 5.1 & 1.4 & - & 83 & 17 \\
\hline $30-1,110-111$ & 14 & 2.9 & - & - & 45 & 0.47 & - & & 32 & 1.78 & - & - & _- & 1.0 & - & - & 92 & 8 \\
\hline $31-2,133-134$ & 1.0 & 2.8 & - & - & 67 & 0.46 & - & & 20 & 1.70 & - & - & - & 1.5 & 4.2 & - & 94 & 6 \\
\hline $34-5,133-134$ & 1.4 & 3.1 & - & - & 19 & 0.41 & - & & 49 & 1.62 & $T$ & - & - & 6.9 & 1.6 & - & 78 & 22 \\
\hline $35-5,113-114$ & 5.5 & 3.0 & - & - & 14 & 0.38 & - & & 58 & 1.68 & $\mathrm{~T}$ & - & - & 6.3 & 1.2 & - & 85 & 15 \\
\hline $36-3,34-35$ & 3.0 & 3.0 & - & - & 30 & 0.40 & - & & 51 & 1.67 & 0.5 & - & - & 3.0 & 0.3 & - & 88 & 12 \\
\hline $37-3,24-25$ & 3.0 & 3.1 & - & - & 45 & 0.37 & - & & 37 & 1.62 & 0.5 & - & - & 6.5 & 0.4 & - & 93 & 7 \\
\hline $38-3,46-47$ & 7.8 & 3.2 & - & - & 33 & 0.35 & - & & 43 & 1.65 & 0.4 & - & - & 5.4 & 0.8 & - & 91 & 9 \\
\hline $39-3,122-123$ & 8.2 & 3.2 & - & - & 22 & 0.32 & - & & 54 & 1.65 & 0.5 & - & - & 7.6 & 1.0 & - & 93 & 7 \\
\hline $40-3,76-77$ & 16 & 3.2 & - & - & 24 & 0.25 & - & & 44 & 1.63 & 0.5 & - & - & 4.4 & 1.0 & - & 90 & 10 \\
\hline $41-3,76-77$ & 18 & 3.2 & - & - & 12 & 0.22 & - & & 57 & 1.65 & - & - & - & 5.2 & - & - & 93 & 7 \\
\hline $42-3,122-123$ & 14 & 2.5 & - & - & - & & - & & 71 & 1.59 & 0.3 & - & - & 6.6 & - & - & 93 & 7 \\
\hline $43-3,127-128$ & 19 & 2.5 & - & - & - & & - & & 72 & 1.60 & $\mathrm{~T}$ & - & - & 4.0 & - & - & 95 & 5 \\
\hline $44-3,73-74$ & 32 & 2.3 & - & - & - & & - & & 5.6 & 1.72 & - & 2.0 & 5.6 & 27 & - & - & 71 & 29 \\
\hline $45-3,41-42$ & 17 & 2.5 & - & - & - & & - & & 67 & 1.65 & - & - & - & 5.8 & - & - & 93 & 7 \\
\hline $46-3,63-64$ & 23 & 2.4 & - & - & - & & - & & 61 & 1.69 & $\mathrm{~T}$ & - & - & 5.0 & - & - & 92 & 8 \\
\hline $47-3,40-41$ & 18 & 2.5 & - & - & - & & - & & 61 & 1.65 & $\mathrm{~T}$ & $\mathrm{~T}$ & $\mathrm{~T}$ & 15 & - & - & 94 & 6 \\
\hline $48-3,45-46$ & 23 & 2.5 & - & - & - & & - & & 52 & 1.65 & - & $\mathrm{T}$ & $\mathrm{T}$ & 9.5 & - & - & 85 & 15 \\
\hline $49-3,83-84$ & 12 & 2.6 & - & - & - & & - & & 60 & 1.65 & - & - & - & 17 & - & - & 89 & 11 \\
\hline $50-3,106-106$ & 10 & 2.3 & - & - & - & & - & & 63 & 1.60 & - & - & $\mathrm{T}$ & 15 & - & - & 88 & 12 \\
\hline $51-2,77-78$ & 9.5 & 2.3 & - & - & - & & - & & 69 & 1.50 & - & - & $\mathrm{T}$ & 15 & - & - & 93 & 7 \\
\hline
\end{tabular}


TABLE 2

Bulk X-Ray Mineralogy Data, Site 366, Hole 366A

\begin{tabular}{|c|c|c|c|c|c|c|c|c|c|c|c|c|c|c|c|c|c|c|}
\hline \multirow[b]{2}{*}{$\begin{array}{c}\text { Sample } \\
\text { (Interval in cm) }\end{array}$} & \multicolumn{2}{|c|}{ Quartz } & \multicolumn{2}{|c|}{ Feldspar } & \multicolumn{2}{|c|}{ Opal-CT } & \multicolumn{2}{|c|}{ Clinoptilolite } & \multicolumn{2}{|c|}{ Calcite } & \multirow{2}{*}{ Halite } & \multirow{2}{*}{ Illite } & \multirow{2}{*}{$\begin{array}{c}\text { Mixed } \\
\text { Layer }\end{array}$} & \multirow{2}{*}{$\begin{array}{c}\text { Smec- } \\
\text { tite }\end{array}$} & \multirow{2}{*}{$\begin{array}{l}\text { Atta- } \\
\text { pulgite }\end{array}$} & \multirow{2}{*}{$\begin{array}{l}\text { Kaoli- } \\
\text { nite }\end{array}$} & \multirow[b]{2}{*}{ Total } & \multirow{2}{*}{$\begin{array}{l}\text { Amorph. } \\
\text { Material }\end{array}$} \\
\hline & $\%$ & $\begin{array}{r}\mathrm{L} 1 / 2 \\
(101)\end{array}$ & Plag & K & $\%$ & $\frac{\mathrm{B}}{\mathrm{A}}$ & $\%$ & $\frac{(200)}{(020)}$ & $\%$ & $\begin{array}{c}\mathrm{L} 1 / 2 \\
(104)\end{array}$ & & & & & & & & \\
\hline $2-3,63-64$ & 5.2 & 1.9 & $\mathrm{~T}$ & 0.8 & & & - & & 51 & 1.60 & 1.6 & 2.0 & 2.5 & 6.6 & - & 6.5 & 77 & 23 \\
\hline $3-3,62-63$ & 3.8 & 1.9 & - & 0.5 & - & & - & & 68 & 1.67 & 1.4 & 1.6 & 0.5 & 2.8 & - & 3.2 & 82 & 18 \\
\hline $4-3,23-24$ & 6.9 & 1.7 & 1.1 & 1.1 & - & & - & & 42 & 1.62 & 1.2 & 6.2 & 1.4 & 5.8 & - & 6.8 & 73 & 27 \\
\hline $5-3,75-76$ & 2.0 & 1.7 & - & $\mathrm{T}$ & - & & - & & 65 & 1.77 & 1.5 & 0.6 & 2.2 & 3.0 & - & 3.6 & 78 & 22 \\
\hline $6-3,69-70$ & 0.8 & & - & $\mathrm{T}$ & - & & - & & 81 & 1.71 & 1.6 & $T$ & - & 0.6 & - & 1.1 & 85 & 15 \\
\hline $7-3,43-44$ & 4.5 & 1.8 & - & 0.5 & - & & - & & 45 & 1.64 & 0.8 & 3.9 & 1.4 & 3.2 & - & 10 & 70 & 30 \\
\hline $8-3,103-104$ & 0.9 & & - & - & - & & - & & 84 & 1.65 & 1.1 & $\mathrm{~T}$ & 2.1 & 1.5 & - & 2.4 & 92 & 8 \\
\hline $9-3,75-76$ & 1.6 & & - & - & - & & - & & 78 & 1.67 & 1.2 & $\mathrm{~T}$ & 0.6 & 0.7 & - & 0.7 & 83 & 17 \\
\hline $10-1,53-54$ & 0.8 & & - & - & - & & - & & 82 & 1.60 & 1.2 & $\mathrm{~T}$ & 0.4 & - & - & 0.5 & 85 & 15 \\
\hline $11-3,53-54$ & 2.5 & & - & - & - & & - & & 73 & 1.50 & 1.3 & $\mathrm{~T}$ & 2.7 & 2.4 & - & 4.0 & 86 & 14 \\
\hline $12-3,108-109$ & 3.0 & & - & - & - & & - & & 62 & 1.52 & 1.2 & 2.8 & 1.7 & 2.0 & - & 6.5 & 80 & 20 \\
\hline $14-3,82-83$ & 5.0 & 1.7 & - & - & - & & - & & 57 & 1.50 & 0.8 & $\mathrm{~T}$ & 6.1 & 1.4 & - & 7.6 & 78 & 22 \\
\hline $15-3,100-101$ & 3.1 & & - & - & - & & - & & 61 & 1.55 & 1.3 & $\mathrm{~T}$ & 3.2 & 1.9 & - & 3.1 & 74 & 26 \\
\hline $16-3,139-140$ & 2.5 & & - & - & - & & - & & 64 & 1.52 & 1.3 & $\mathrm{~T}$ & 2.1 & 2.1 & - & 3.2 & 75 & 25 \\
\hline $17-3,92-93$ & 1.3 & & - & - & - & & - & & 68 & 1.50 & 1.0 & $\mathrm{~T}$ & 3.2 & 1.9 & - & 2.2 & 78 & 22 \\
\hline $18-3,82-83$ & 1.3 & & - & - & - & & - & & 74 & 1.50 & 1.6 & - & 1.6 & 2.6 & - & 2.1 & 83 & 17 \\
\hline $10-3,105-106$ & 1.1 & & - & - & - & & - & & 77 & 1.57 & 1.3 & - & 2.1 & 1.4 & - & 2.8 & 86 & 14 \\
\hline $21-3,77-78$ & 0.5 & & - & - & - & & - & & 72 & 1.52 & 1.1 & - & - & 2.7 & - & 1.6 & 78 & 22 \\
\hline $23-3,99-100$ & 4.7 & 1.7 & - & - & - & & - & & 17 & 1.62 & 1.5 & - & - & 9.4 & - & 14 & 47 & 53 \\
\hline $24-2,93-94$ & 0.9 & & - & - & - & & - & & 72 & 1.53 & 1.3 & - & 1.0 & 2.2 & - & 2.0 & 80 & 20 \\
\hline $26-3,82-83$ & - & & - & - & 9.0 & 0.40 & - & & 82 & 1.50 & 0.4 & - & - & 3.1 & - & - & 95 & 5 \\
\hline $26-3,116-117$ & - & & - & - & - & & - & & 83 & 1.50 & 1.3 & - & - & 4.0 & - & 1.2 & 90 & 10 \\
\hline $27-3,109-110$ & 0.8 & & - & - & - & & - & & 70 & 1.55 & 1.2 & - & - & 2.6 & - & 2.1 & 77 & 23 \\
\hline $28-3,73-74$ & - & & - & - & - & & - & & 70 & 1.52 & 1.0 & - & - & 3.2 & - & 2.1 & 77 & 23 \\
\hline $29-3,75-76$ & 1.0 & & - & - & - & & 2.0 & 4.7 & 72 & 1.57 & 1.7 & - & - & 6.0 & - & 2.0 & 85 & 15 \\
\hline $30-3,52-53$ & 1.0 & & - & - & - & & 2.8 & 2.3 & 67 & 1.60 & 0.9 & $\mathrm{~T}$ & 2.1 & 3.9 & - & 2.5 & 81 & 19 \\
\hline $31-3,82-83$ & - & & - & - & - & & $\mathrm{T}$ & & 79 & 1.58 & 1.1 & - & - & 1.1 & - & 0.7 & 82 & 18 \\
\hline $33-3,82-83$ & 0.4 & & - & - & - & & - & & 70 & 1.60 & 0.8 & - & - & 5.8 & - & 1.9 & 79 & 21 \\
\hline $34-3,77-78$ & 1.5 & & - & - & - & & 1.4 & 3.6 & 66 & 1.65 & 0.7 & - & $\mathrm{T}$ & 5.3 & - & 3.4 & 79 & 21 \\
\hline $35-3,74-75$ & 0.4 & & - & - & - & & 1.9 & 1.0 & 74 & 1.55 & 0.9 & - & $\begin{array}{ll}- \\
-\end{array}$ & 2.7 & - & $T$ & 80 & 20 \\
\hline $36-3,52-53$ & 1.4 & & - & - & - & & 1.8 & 1.2 & 65 & 1.62 & 0.9 & - & 1.7 & 3.6 & - & 2.1 & 77 & 23 \\
\hline $37-3,95-96$ & 0.4 & & - & - & - & & 1.6 & 1.4 & 76 & 1.55 & 0.8 & - & 2.1 & 4.2 & - & - & 85 & 15 \\
\hline $38-3,44-45$ & 0.4 & & - & - & - & & 2.5 & 1.2 & 80 & 1.52 & 0.9 & - & - & 1.2 & - & - & 85 & 15 \\
\hline
\end{tabular}




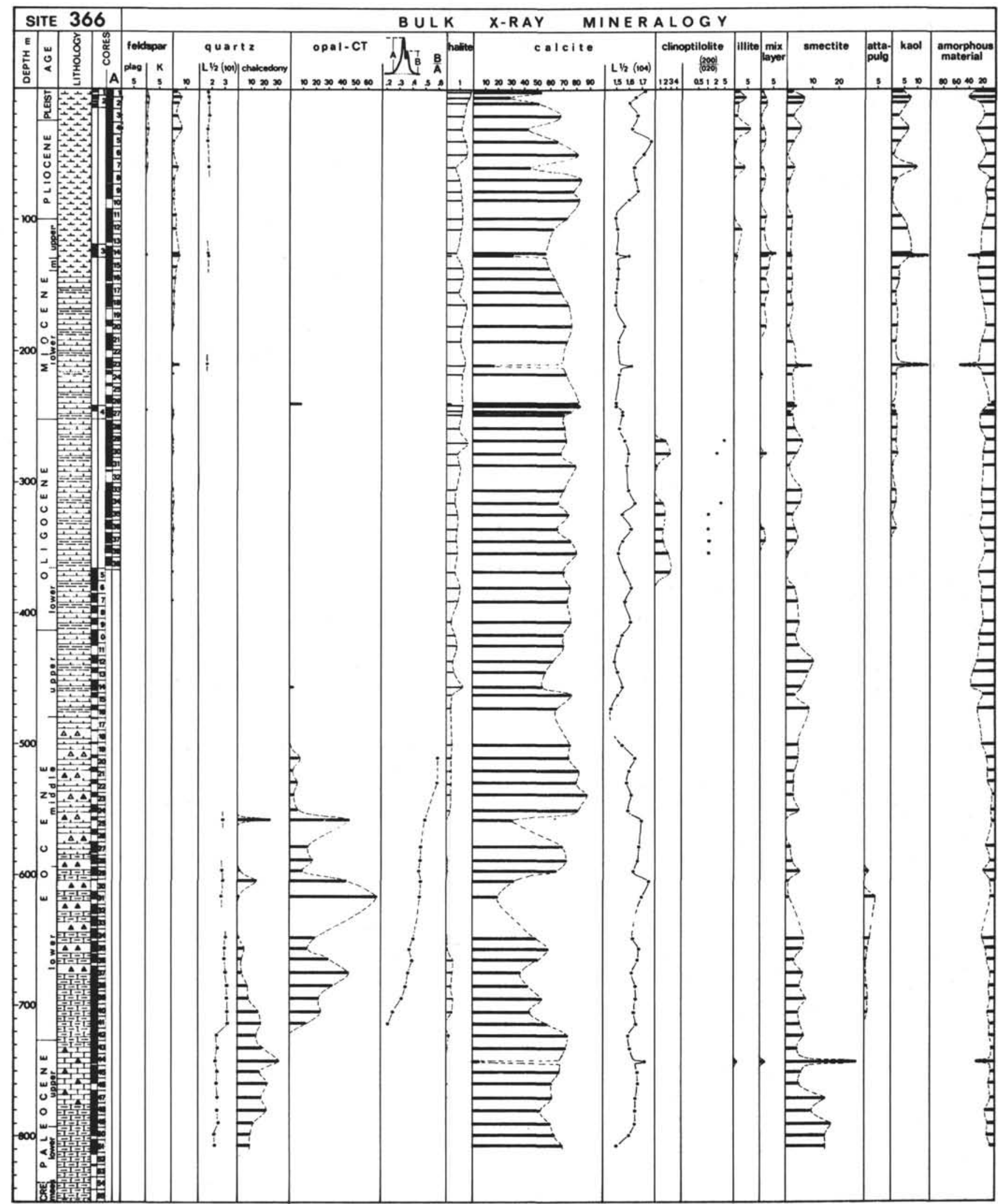

Figure 2. Bulk X-ray mineralogy data, Site 366.

materials, and by subtraction from 100 , to estimate the amorphous material content; and (2) combined with the water content value of a sediment (often known from shipboard measurement), the halite content value may yield an interesting indication about the salinity value (in terms of $\mathrm{NaCl}$ ) of the interstitial water. 
TABLE 3

Bulk X-Ray Mineralogy Data, Site 367

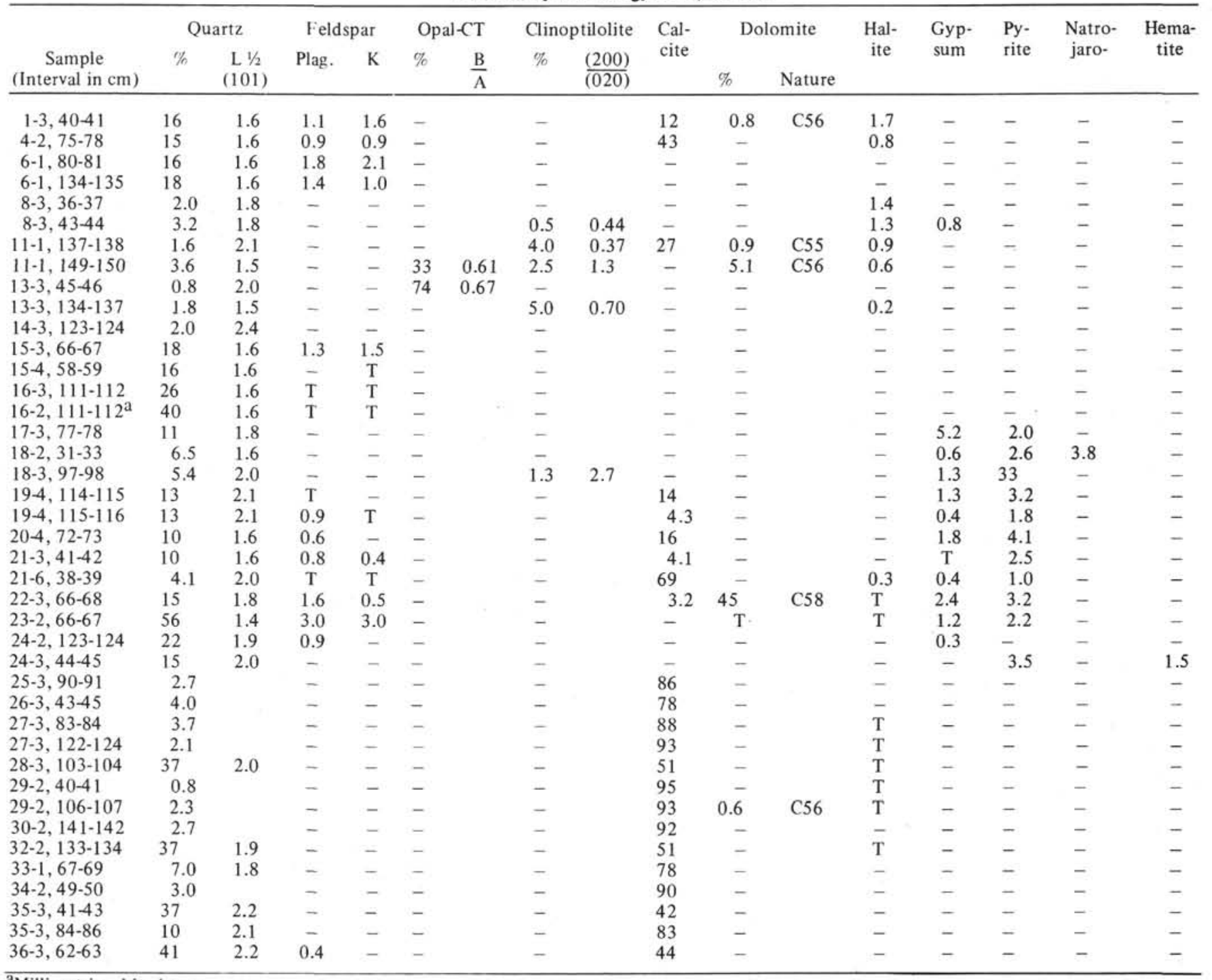

${ }^{\mathrm{a}}$ Millimetric white layer.

\section{Clay Minerals}

The amounts of clay minerals were estimated using the peaks area above the background on diffractograms from glycolated samples. The $10 \AA$ peak was used for illite and the $17 \AA$ was used for smectite (this procedure includes part of the expandable irregular mixed-layer clays). The $7 \AA$ peak yields the total amount of chlorite + kaolinite, the balance between these minerals being derived from the peak-height ratio, at $3.54 \AA$ and $3.58 \AA$, respectively, according to the method described by Biscaye (1964). The amount of irregular mixed-layer clays (mainly illite-smectite derived from illitic material by opening the $10 \AA$ layers) was estimated from the area above the background between the $10 \AA$ peak of illite and that of smectite at $17 \AA$. This procedure underestimates the true amount of mixed-layer clays because the expandable part of these minerals is more or less incorporated in the $17 \AA$ peak area through the ethylene-glycol treatment. The amounts of attapulgite and sepiolite were estimated from the (110) peak area above the background, corrected for mixed-layer influence by comparison of diffractograms from both glycolated and unglycolated samples.

\section{Amorphous Material}

The use of an internal standard to measure the absolute percentages of each crystallized constituent allows an estimation of the amount of amorphous material by subtracting the total of all crystallized constituents from 100 . Such a procedure was attempted despite a large imprecision in the results, especially for low values.

\section{RESULTS AND DISCUSSION}

Analytical data are given in Tables 1 to 7 ; they are presented as mineralogical logs for each site in Figures 2 to 6 . Figure 1 shows the location of Leg 41 drill sites.

\section{Site 366-Sierra Leone Rise}

Site 366 is located on the upper part of Sierra Leone Rise, about $800 \mathrm{~km}$ southwest of the African coast, in 2860 meters of water. The section was continuously cored down to a depth of 850.5 meters, recording a 
TABLE 3 - Continued

\begin{tabular}{|c|c|c|c|c|c|c|c|c|c|}
\hline Goethite & Illite & $\begin{array}{l}\text { Mixed } \\
\text { Layer }\end{array}$ & Smectite & $\begin{array}{c}\text { Atta- } \\
\text { pulgite }\end{array}$ & Sepiolite & Chlorite & Kaolinite & Total & $\begin{array}{l}\text { Amorph. } \\
\text { Material }\end{array}$ \\
\hline- & 2.6 & 4.0 & 7.5 & - & - & 2.6 & 7.9 & 60 & 40 \\
\hline- & 0.5 & 1.6 & 1.6 & - & - & 1.3 & 2.2 & 72 & 28 \\
\hline- & 2.6 & 7.7 & 7.2 & - & - & - & 21 & 59 & 41 \\
\hline- & 1.4 & 6.9 & 20 & - & _ & - & 20 & 69 & 31 \\
\hline- & - & 9.0 & 17 & 8.0 & 18 & - & 2.0 & 58 & 42 \\
\hline - & - & 2.3 & 13 & 1.4 & 1.2 & - & 3.0 & 27 & 73 \\
\hline- & - & 1.6 & 17 & 10 & 3.6 & - & - & 70 & 30 \\
\hline- & - & 6.3 & 8.7 & 17 & 2.8 & - & - & 80 & 20 \\
\hline - & - & - & 1.7 & 13 & - & - & - & 89 & 11 \\
\hline- & - & $\mathrm{T}$ & 37 & 17 & 11 & - & - & 72 & 28 \\
\hline - & - & 7 & 12 & 36 & 39 & - & - & 96 & 4 \\
\hline- & - & 7.6 & 16 & - & - & - & 7.9 & 52 & 48 \\
\hline- & 1.8 & 7.3 & 16 & - & _- & - & 8.7 & 51 & 49 \\
\hline- & - & 2.7 & 28 & - & - & - & 5.0 & 62 & 38 \\
\hline- & 1.1 & 3.0 & 27 & - & _- & - & 5.8 & 77 & 23 \\
\hline - & 0.9 & 3.1 & 19 & 7.1 & - & - & 3.9 & 54 & 46 \\
\hline- & $\mathrm{T}$ & 1.7 & 2.7 & 3.5 & - & - & - & 23 & 77 \\
\hline- & - & 2.6 & 10 & - & - & - & - & 54 & 46 \\
\hline- & - & 3.5 & 32 & - & - & - & - & 68 & 32 \\
\hline- & 0.6 & 1.6 & 24 & 2.0 & - & - & - & 49 & 51 \\
\hline - & 1.3 & 4.9 & 10 & - & - & - & 3.9 & 53 & 47 \\
\hline- & 1.9 & 5.4 & 8.8 & - & - & - & 5.4 & 40 & 60 \\
\hline- & 0.7 & 2.6 & 4.9 & - & _ & - & 2.0 & 85 & 15 \\
\hline- & 2.6 & 7.1 & 3.8 & - & - & - & 4.6 & 88 & 12 \\
\hline- & 2.4 & 1.3 & 13 & - & _ & - & 4.0 & 88 & 12 \\
\hline- & 3.9 & 4.7 & 25 & - & - & - & 6.7 & 64 & 36 \\
\hline 1.6 & 2.2 & 4.3 & 34 & - & - & - & 4.1 & 67 & 33 \\
\hline- & - & - & 3.1 & - & - & - & - & 92 & 8 \\
\hline - & - & 0.8 & 2.8 & - & - & - & - & 86 & 14 \\
\hline - & - & - & 1.3 & - & - & - & - & 93 & 7 \\
\hline - & - & - & - & - & _- & _- & - & 95 & 5 \\
\hline- & - & 1.6 & 0.7 & - & - & - & - & 91 & 9 \\
\hline- & - & - & $\mathrm{T}$ & - & - & - & - & 96 & 4 \\
\hline - & - & - & - & - & - & - & - & 96 & 4 \\
\hline- & - & $\mathrm{T}$ & $T$ & _ & _ & - & - & 95 & 5 \\
\hline- & 1.4 & 1.2 & 2.6 & - & - & - & - & 94 & 6 \\
\hline- & - & 1.6 & 1.9 & - & - & - & - & 89 & 11 \\
\hline - & - & - & 3.0 & - & - & - & - & 96 & 4 \\
\hline - & 1.1 & 4.5 & 1.3 & - & - & - & - & 86 & 14 \\
\hline - & - & 1.9 & 1.5 & - & - & _- & - & 97 & 3 \\
\hline - & 1.2 & 3.9 & 1.5 & - & - & - & - & 92 & 8 \\
\hline
\end{tabular}

complete Cenozoic sequence. Seventy-eight samples were submitted for X-ray analysis (Tables 1 and 2; Figure 2).

The sedimentary section is characterized mineralogically by high values of calcite, ranging from $60 \%$ to $80 \%$; the average value is very constant, except for: (1) a decrease toward the top of the section (upper Miocene and Pliocene-Quaternary); and (2) large variations in the lower part of the section (below the middle Eocene). These variations result from dilution by other mineralogical constituents. The generally high calcite content suggests that the sea floor of the Sierra Leone Rise remained above the level of the carbonate compensation depth (CCD) since at least the early Paleocene.

\section{Terrigenous Detrital Material}

The variations of the crystallinity of quartz show that two types of quartz occur: (1) terrigenous detrital quartz $(11 / 2[101]=1.7 \pm 0.1)$, and $(2)$ authigenic quartz or chalcedony ( $\mathrm{L} \mathrm{1/2}$ [101] values ranging from 2.3 to 3.2) (see preceding paragraph, "Comments on Mineralogical Data"). The first type of quartz occurs only in the upper part of the section; it appears as traces in the Oligocene, increases slightly in the middle and upper Miocene (3\% to $5 \%$ ), and reaches a maximum in the Pliocene-Quaternary; however, the percentages remain very low (maximum $7 \%$ ).

Although feldspars occur only in the PlioceneQuaternary sediments, the variation of their amounts correlates well with that of quartz. The prominence of $\mathrm{K}$-feldspar among these feldspars suggests a high degree of evolution of the terrigenous material.

The variation of the influence of terrigenous input is remarkably well illustrated by the variation of the kaolinite abundance. Kaolinite is probably the best marker of terrigenous input in low latitudes and in the vicinity of Africa (Biscaye, 1965). This mineral, together with quartz, first appears in the middle Oligocene in very low but constant amounts (2\% to $3 \%$ ), has a slight maximum in the upper Miocene (6\%), and then correlates with quartz + feldspar in the PlioceneQuaternary (maximum 10\%).

The variations of illite and mixed-layer content confirm the variations of the terrigenous input. Smectite correlates with the Pliocene-Quaternary 
TABLE 4

Bulk X-Ray Mineralogy Data, Site 368

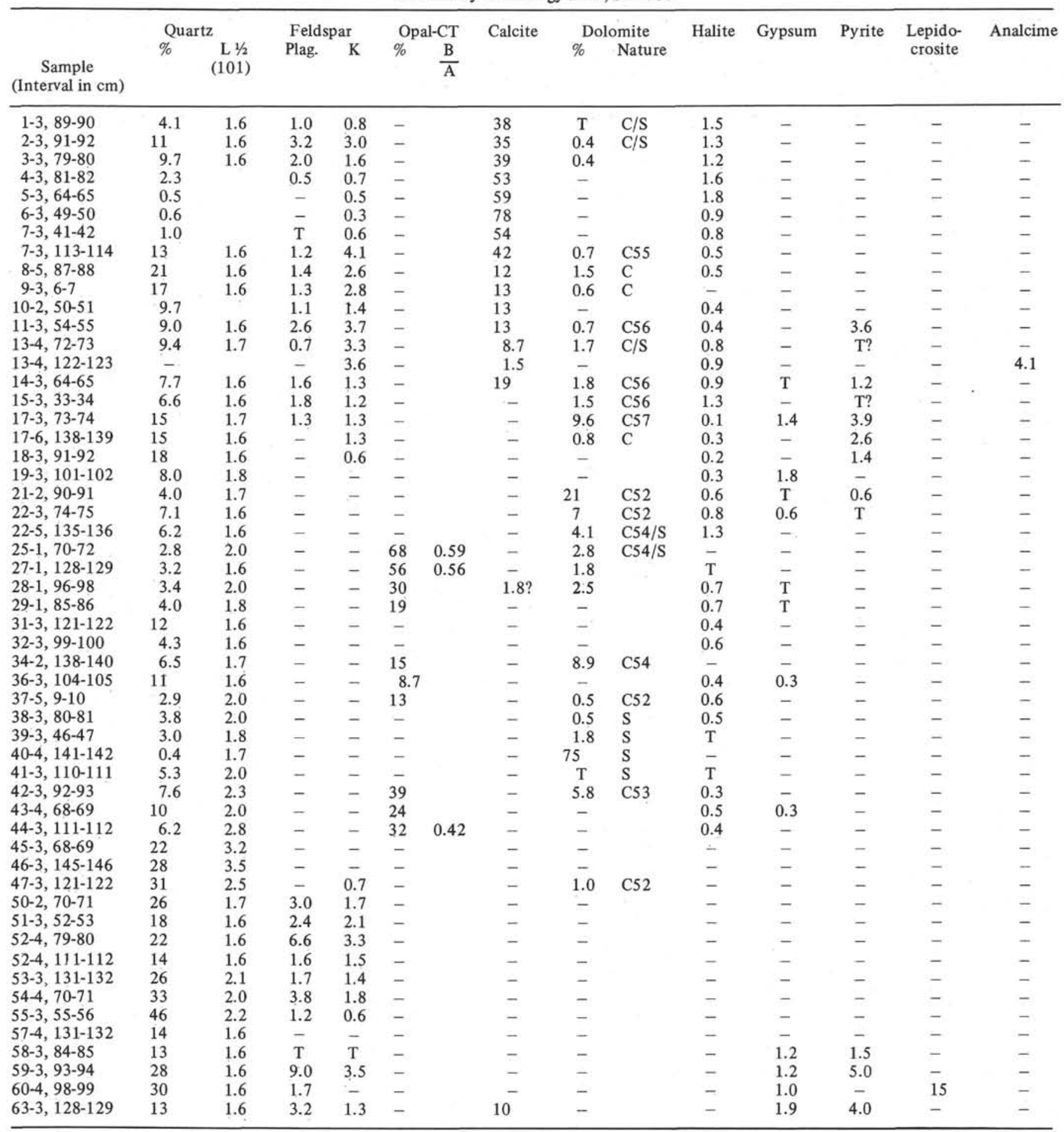

pattern of the preceding minerals, and therefore appears to be of terrigenous origin. Smectite is present in minor but noticeable amounts (averaging 10\%) below the middle Oligocene, and down to the base of the section, except at the base (Paleocene) where higher percentages occur (up to $27 \%$ ). Smectite is probably the only terrigenous constituent able to reach the site because of its very small grain size. Attapulgite occurs in very small amounts in the lower Eocene (maximum $4 \%$ ). The occurrence of this mineral appears unrelated to that of other terrigenous material, which poses the problem of its origin. In any case, the environmental conditions on Sierra Leone Rise did not favor the authigenesis of attapulgite, which appears more likely to be of terrigenous origin, as will be seen below (Sites 367 and 368).

\section{Non-Terrigenous Crystalline Silica}

Crystalline silica, either as opal-CT or as chalcedony, constitutes a notable to dominant part of the sediment in the Paleocene and in the lower and middle Eocene (percentages reaching $60 \%$ ). 
TABLE 4 - Continued

\begin{tabular}{|c|c|c|c|c|c|c|c|c|}
\hline Illite & $\begin{array}{l}\text { Mixed } \\
\text { Layer }\end{array}$ & Smectite & $\begin{array}{l}\text { Atta- } \\
\text { pulgite }\end{array}$ & $\begin{array}{l}\text { Sepio- } \\
\text { lite }\end{array}$ & Chlorite & $\begin{array}{l}\text { Kaoli- } \\
\text { nite }\end{array}$ & Total & $\begin{array}{l}\text { Amorph } \\
\text { Material }\end{array}$ \\
\hline 3.6 & 0.9 & 1.2 & - & - & - & 2.6 & 54 & 46 \\
\hline 9.4 & 2.4 & 3.5 & - & - & 1.0 & 5.5 & 76 & 24 \\
\hline 6.3 & 1.9 & 6.9 & - & - & - & 5.0 & 77 & 23 \\
\hline 2.9 & 1.5 & 4.3 & - & - & - & 2.9 & 70 & 30 \\
\hline 0.6 & 0.8 & 2.6 & - & - & - & 1.5 & 68 & 32 \\
\hline $\mathrm{T}$ & 0.6 & $T$ & - & - & - & 1.8 & 83 & 17 \\
\hline 0.8 & 1.2 & 2.0 & - & - & - & 2.1 & 63 & 37 \\
\hline 7.2 & 1.2 & 1.7 & - & - & - & 5.5 & 77 & 23 \\
\hline 3.3 & 4.6 & 3.2 & - & - & - & 8.4 & 59 & 41 \\
\hline 5.1 & 4.5 & 4.1 & - & - & - & 10 & 59 & 41 \\
\hline $\mathrm{T}$ & 4.5 & 7.4 & - & - & - & 10 & 48 & 52 \\
\hline 1.8 & 2.7 & 12 & - & - & - & 5.5 & 56 & 44 \\
\hline 1.2 & 4.0 & 6.8 & - & - & - & 7.7 & 45 & 55 \\
\hline- & 1.1 & 1.8 & - & - & - & 0.8 & 14 & 86 \\
\hline 1.2 & 4.5 & 8.8 & - & - & - & 4.0 & 52 & 48 \\
\hline 1.6 & 5.1 & 12 & - & - & - & 7.0 & 38 & 62 \\
\hline 2.0 & 3.4 & 12 & - & - & - & 11 & 62 & 38 \\
\hline 2.2 & 2.3 & 11 & 0.9 & - & - & 11 & 49 & 51 \\
\hline $\mathrm{T}$ & 1.9 & 11 & 4.3 & 0.8 & - & 14 & 52 & 48 \\
\hline $\mathrm{T}$ & 3.1 & 14 & 28 & 2.6 & - & 9.5 & 68 & 32 \\
\hline- & - & 2.6 & 30 & 3.3 & - & - & 62 & 38 \\
\hline- & - & 4.0 & 63 & - & - & - & 83 & 17 \\
\hline- & - & 5.0 & 69 & - & - & - & 86 & 14 \\
\hline- & - & 1.2 & 20 & - & - & - & 95 & 5 \\
\hline- & - & 2.0 & 27 & - & - & - & 91 & 9 \\
\hline- & - & 4.0 & 42 & - & - & - & 85 & 15 \\
\hline- & - & 6.0 & 59 & - & - & - & 89 & 11 \\
\hline- & - & 14 & 63 & $\mathrm{~T}$ & - & - & 89 & 11 \\
\hline- & - & 12 & 66 & 4.3 & - & - & 91 & 9 \\
\hline- & - & 10 & 43 & 4.5 & - & - & 88 & 12 \\
\hline- & - & 6.4 & 52 & 10 & - & - & 89 & 11 \\
\hline- & - & 1.2 & 33 & 44 & - & - & 95 & 5 \\
\hline- & - & 8.6 & 52 & 32 & - & - & 97 & 3 \\
\hline- & - & 3.0 & 55 & 35 & - & - & 98 & 2 \\
\hline - & - & 1.7 & 7 & 2.9 & - & - & 87 & 13 \\
\hline - & - & 6.1 & 47 & 37 & - & - & 95 & 5 \\
\hline- & - & 4.0 & 27 & 8.0 & - & - & 92 & 8 \\
\hline- & - & 10 & 29 & 6.0 & - & - & 80 & 20 \\
\hline- & - & 3.8 & 33 & 6.1 & - & - & 82 & 18 \\
\hline - & - & 13 & 28 & 18 & - & - & 81 & 19 \\
\hline - & - & 21 & 11 & 16 & - & - & 77 & 23 \\
\hline- & - & 21 & 6.1 & 6.9 & - & - & 67 & 33 \\
\hline 1.6 & 5.0 & 17 & - & - & - & 7.8 & 62 & 38 \\
\hline 1.9 & 5.2 & 23 & - & - & - & 14 & 67 & 33 \\
\hline 2.2 & 5.9 & 17 & 2.0 & - & - & 4.5 & 64 & 36 \\
\hline 2.3 & 7.5 & 5.6 & 7.0 & - & - & 5.6 & 45 & 55 \\
\hline 2.3 & 3.5 & 11 & 6.1 & - & 0.5 & - & 53 & 47 \\
\hline 5.2 & $\mathrm{~T}$ & 23 & 7.3 & - & 2.5 & - & 77 & 23 \\
\hline 1.2 & 2.8 & 12 & 4.9 & - & 0.6 & - & 70 & 30 \\
\hline - & 6.1 & 44 & - & - & - & - & 64 & 36 \\
\hline 3.4 & 12 & 17 & - & - & - & 6.8 & 56 & 44 \\
\hline 19 & 3.1 & 21 & - & - & 3.8 & 1.4 & 95 & 5 \\
\hline 38 & - & 4.5 & - & - & 3.7 & - & 94 & 6 \\
\hline 12 & 4.0 & 19 & - & - & 2.3 & - & 71 & 29 \\
\hline
\end{tabular}

Opal-CT, thought to result from the evolution of biogenic amorphous silica (Heath and Moberly, 1971; Lancelot, 1973; Keene, 1975), occurs here only in lower and middle Eocene sediments, a well-known and worldwide documented stratigraphic occurrence. The amount of opal-CT in the sediment fluctuates largely from sample to sample but reaches $60 \%$. The B/A ratio (see "Comments on Mineralogical Data") decreases progressively from the top $(0.6)$ to the base $(0.2)$ of the opal-CT episode.

Chalcedony occurs mainly in Paleocene sediments (average 20\%) and, to a minor extent, in lower Eocene sediments. In lower Eocene sediments where opal-CT is well developed, the crystallinity of chalcedony has a very constant value $(\mathrm{L} 1 / 2[101]=3.2)$. In the Paleocene, devoid of opal-CT, the crystallinity of chalcedony also has a very constant value ( $\mathrm{L} 1 / 2$ [101] $=2.3$ ), but the degree of crystallinity is higher than in the opal-CT zone. This abrupt change in the crystallinity of chalcedony is remarkable and coincides with the downward disappearance of opal-CT.

Opal-CT is progressively replaced downward by chalcedony as shown by the variations in the relative abundance and the crystallinity of both chalcedony and 
TABLE 5

Bulk X-Ray Mineralogy Data, Site 369, Hole 369

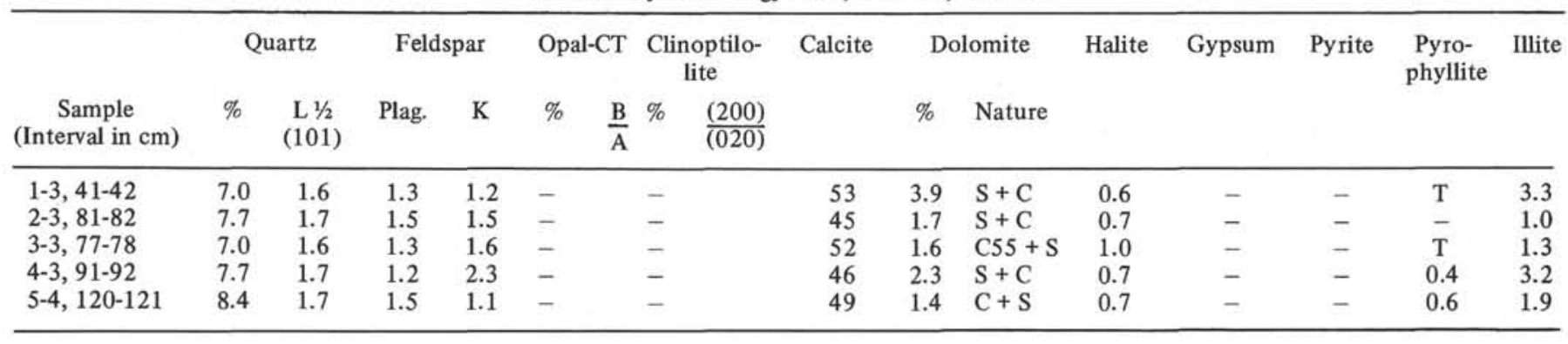

opal-CT from the middle Eocene to the Paleocene. Detailed petrographic studies have clearly demonstrated that in cherts opal-CT can be transformed into chalcedony through maturation processes (Heath and Moberly, 1971; Keene, 1975). However, Site 366 offers, for the first time in my knowledge, the possibility to follow the complete transformation of opal-CT into chalcedony, on a stratigraphic scale. The B/A ratio of opal-CT appears as a precious indicator of maturity of this mineral in such a transformation. Further detailed studies, based on a more specifically oriented sampling, obviously are necessary for a better understanding of the meaning of the B/A ratio in the process of chert genesis.

\section{Clinoptilolite}

This mineral occurs in minor amounts, ranging from $1 \%$ to $3 \%$, in Oligocene sediments; it does not show any correlation with other minerals. Clinoptilolite is generally thought to be derived from volcanic material (Deffeyes, 1959; Hathaway and Sachs, 1965), and its occurrence here may be the result of a volcanic episode during the Oligocene. The values of the $(200) /(020)$ peak-height ratio (see "Comments on Mineralogical Data") are high.

\section{Calcite}

Calcite is by far the most abundant mineralogical constituent of Site 366 sediments and, because of the physiographic position of this site, results exclusively from biologic production except perhaps in the uppermost part of the section where one notes a slight terrigenous influence. An accurate measurement of the calcite crystallinity was carried out (see preceding paragraph "Comments on Mineralogical Data") because of this biogenic origin.

The curve of L 1/2 (104) values (Figure 2) shows significant variations. The best crystallinities (lowest $\mathrm{L}$ $1 / 2$ [104] values) occur in the Miocene; a sharp break occurs at the Miocene/Pliocene boundary and, in the Pliocene-Quaternary sediments, the crystallinities are poor (highest L 1/2 [104] values). Oligocene sediments are characterized by intermediate values. The crystallinity in the upper Eocene is good and similar to that of the Miocene, but from the top of the middle Eocene down to the base of the Paleocene (opal-CT + chalcedony zone), the $L 1 / 2$ (104) values average 1.7 , indicating poor crystallinities of the calcite. The interpretation of the crystallinity curve is only tentative in the absence of data on calcite dissolution and recrystallization processes (SEM) and paleotempera- tures (stable isotopes). Nevertheless, an attempt will be made, taking into account two parameters influencing the crystallinity of biogenic calcite: (1) environment of growth of the organisms; and (2) recrystallization processes.

1) Influence of environment: Beside the availability of nutrients, the temperature of the surface waters could be an important factor influencing the production of calcareous organisms. Generally speaking, the best conditions for non-stressed niches are encountered in warm rather than cold surface waters. As a consequence of the growth rate of the calcareous tests, the crystallinity of calcite would be better in cold waters (slow growth) than in warm waters (fast growth); this tentative statement obviously needs further investigation to be confirmed. Consequently, low L $1 / 2$ (104) values could correspond to periods characterized by a low productivity in relatively cold surface waters, and high L $1 / 2$ (104) values would correspond to periods characterized by a higher productivity.

2) Recrystallization: Calcite recrystallization in diagenetic processes depends mainly in porosity and permeability of the sediment, which controls the circulation of pore waters. Recrystallization is most effective in calcareous lithologies, and much more limited in sediments rich in fine particles (clay minerals and/or diagenetic silica). Recrystallization results in an increase in the degree of crystallinity (decrease of $\mathrm{L} 1 / 2$ [104] value).

In light of the above parameters, the variations of the curve of calcite crystallinity at Site 366 is interpreted as follows. The break at the Miocene/Pliocene boundary resulted from a climatic change from cold (Miocene) to warm (Pliocene) conditions in the overlying surface waters. The influence of recrystallization on the calcite crystallinity could not account for the difference in the crystallinity values on each side of the break because there is no significant change in lithology (clay content) through the break. Relatively cold surface water conditions during the Miocene (and even in the very early Pliocene, Core 366A-11) resulted in a low biological productivity (slow growth of calcareous tests, yielding a good calcite crystallinity), whereas during the Pliocene, warmer conditions favored a higher productivity (fast growth of calcareous tests, yielding a poor calcite crystallinity). This interpretation seems to be supported by the difference in the accumulation rates during the Miocene $(8.8 \mathrm{~mm} / 1000$ $\mathrm{yr})$ and the Pliocene $(25 \mathrm{~mm} / 1000 \mathrm{yr})$.

The poor crystallinities of the calcite in the lower part of the section, below Core 366-20 (from middle Eocene 
TABLE 5 - Continued

\begin{tabular}{lcccccc}
\hline $\begin{array}{c}\text { Mixed } \\
\text { Layer }\end{array}$ & $\begin{array}{c}\text { Smec- } \\
\text { tite }\end{array}$ & $\begin{array}{c}\text { Atta- } \\
\text { pulgite }\end{array}$ & Chlorite & $\begin{array}{c}\text { Kaoli- } \\
\text { nite }\end{array}$ & Total & $\begin{array}{c}\text { Amorph. } \\
\text { Material }\end{array}$ \\
\hline 9.8 & 1.1 & - & 1.8 & 2.3 & 86 & 14 \\
6.0 & 2.9 & - & 1.9 & 2.1 & 72 & 28 \\
4.8 & 3.4 & - & 1.5 & 1.8 & 78 & 22 \\
5.5 & 3.3 & - & 2.0 & 2.3 & 77 & 23 \\
4.1 & 2.4 & - & 1.2 & 2.5 & 75 & 25 \\
\hline
\end{tabular}

to Paleocene) are more difficult to interpret. The remarkable coincidence of the poor crystallinities with the occurrence of diagenetic silica in the sediment, either as opal-CT or as chalcedony, suggests that this silica may have prevented the recrystallization of calcite. However, it is also possible that warmer conditions prevailed from the Paleocene until the middle Eocene (accumulation rate: $18 \mathrm{~mm} / 1000 \mathrm{yr}$ ) than existed during the upper Eocene and the Oligocene (accumulation rate: $11 \mathrm{~mm} / 1000 \mathrm{yr}$ ).

Whatever the interpretation of the calcite crystallinity at Site 366 , the parallelism between the crystallinities and the accumulation rates is conspicuous and should promote further investigations in this field.

\section{Dolomite}

The total lack of dolomite at Site 366 suggests that this mineral does not form as an authigenic phase, in a purely pelagic carbonate environment. As a common constituent of marine sediments, dolomite may therefore owe its origin, at least in part, to terrigenous particles of dolomite, which may have acted finally as nuclei for further crystallization.

\section{Amorphous Material}

The amount of amorphous material is estimated by subtraction of the sum of the percentages of crystallized minerals from 100. The curve variation of the amorphous material content shows that: (1) there is a good correlation between the abundance of amorphous material and terrigenous material (quartz + feldspar + clays), in the whole Pliocene-Quaternary, and in the Miocene (366-3-5, $75 \mathrm{~cm}$ and 366A-23-3, $99 \mathrm{~cm}$ ) and in the upper Paleocene $(366-44-3,73 \mathrm{~cm})$. This suggests that at least part of the amorphous material is of terrigenous origin; (2) the content of amorphous material is noticeably less abundant in the recrystallized silica zone (Paleocene to middle Eocene) than in the upper part of the section. This suggests that the amorphous material in this upper part may consist partly of amorphous biogenic silica (diatoms and radiolarians) that has not been transformed into opalCT or chalcedony.

\section{Site 367-Cape Verde Basin}

Site 367 is located on the lowermost part of the African Continental Rise off southern Senegal, in 4748 meters of water. It was cored discontinuously down to 1153 meters, reaching basalt below KimmeridgianOxfordian carbonate rocks. Forty samples were submitted for X-ray analysis (Table 3); results are presented in Figure 3, in which the horizontal bars (percentages) have not been vertically linked because the section is too poorly documented (discontinuous coring and too few samples). Nevertheless, all the lithological units (see site chapter) are mineralogically well characterized.

Upper Jurassic to Neocomian limestone consists of calcite with minor amounts of quartz and clay minerals (smectite and mixed-layer). Quartz occurs locally as chalcedony in the cherty limestone facies. There are no feldspars, and the content of amorphous material is extremely low. These features suggest that the source terrain on land had very low relief.

Barremian to lower Albian variegated claystone consists exclusively of terrigenous material (quartz, feldspars, clay minerals), with a prominence of $\mathrm{K}$ feldspar over plagioclase. This material accumulated in a restricted environment (pyrite and gypsum), probably below the CCD, as suggested by the total lack of calcite.

Albian-Cenomanian black shale is similar mineralogically to the underlying claystone, but differs in four points; (1) considerable increase in the amorphous material content; (2) occurrence of calcite; (3) lower quartz content; (4) prominence of plagioclase over Kfeldspar. The nature of the amorphous material is critical for an interpretation of such a facies. If this material is mainly organic in nature, then the above features may indicate that, although the depositional environment remained restricted, the rate of accumulation was high enough to prevent oxidation of the organic matter, as well as total dissolution of calcite.

Upper Cretaceous to Paleocene silty clay is mineralogically very similar to the Barremian to lower Albian claystone, except that they do not contain pyrite and gypsum, and have a higher amorphous material content. Apart from the amorphous material, they consist exclusively of crystalline terrigenous material (quartz, feldspars, kaolinite, and smectite), probably deposited below the CCD, in normal marine conditions.

Eocene siliceous and zeolitic clay is devoid of the "classical" terrigenous assemblage (quartz, feldspars, micas, and kaolinite). They consist mainly of attapulgite and sepiolite, showing clear positive correlation in the variations of their amounts. This suggests a similar origin for both minerals. Smectite occurs in noticeable amounts. Crystalline silica occurs only in sediments of lower and middle Eocene age mainly as immature opal-CT, as indicated by its high B/A ratio (see Site 366), and as minor amount of chalcedonic quartz. Clinoptilolite occurs also mainly in lower and middle Eocene sediments, and constitutes up to $5 \%$ of the sediment; its $(200) /(020)$ peak height ratio does not show any significant variation.

The problem of the origin of both attapulgite and sepiolite can be solved in light of onshore data. Millot (1964, p. 308-320), in an outstanding synthesis of the mineralogical and geochemical data concerning the African basins, pointed out that during the Paleocene and the lower Eocene, a "sédimentation chimique basique" developed intensively as the result of a tropical and humid climate, and in relation with a general transgression. Solubilized products of 
TABLE 6

Bulk X-Ray Mineralogy Data, Site 369, Hole 369A

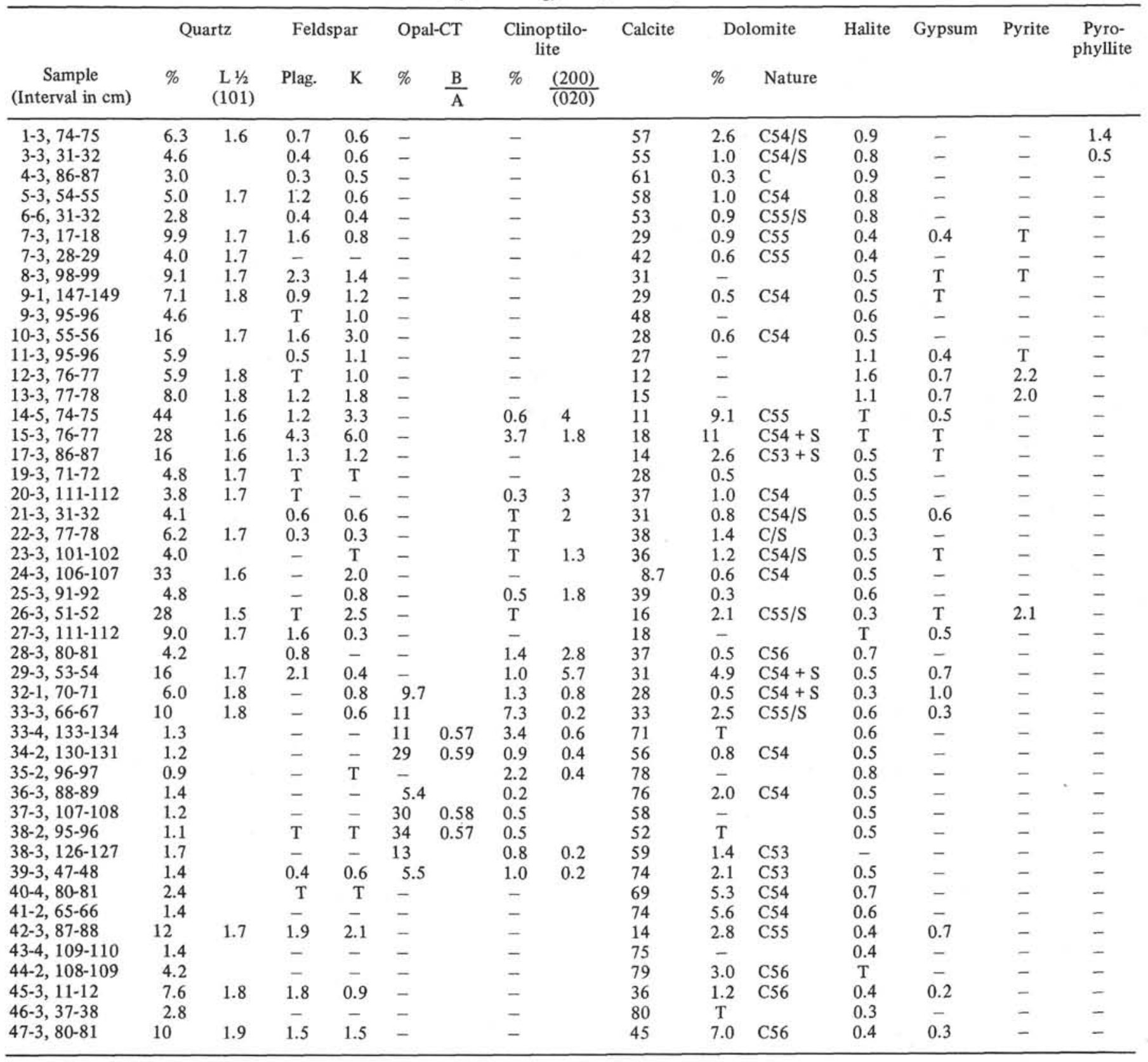

weathered continental rocks filled the African sedimentary basins, where huge masses af attapulgite and sepiolite were generated through this chemical sedimentation. The thickness of attapulgite and sepiolite deposits in the Senegal basin reaches 500 meters, and two maxima of sepiolite abundance occur, the first in the upper Paleocene and the second in the lower Eocene. It is not surprising that considerable amounts of attapulgite and sepiolite escaped the Senegal basin because this marginal basin is widely open toward the Atlantic Ocean. These minerals settled in the deep ocean, probably incorporated in more or less distal turbidites, depending on the physiographic environment and the distance from the continent. This event was also recorded within purely pelagic sediments at Site 366 (Sierra Leone Rise) where relatively small amounts of attapulgite occur in the lower Eocene. The attapulgite of Site 366 can now be interpreted as an allochthonous constituent in the light of the preceding discussion. The mineralogical data at Site 367 are too scarce to determine whether or not the two maxima of sepiolite are indeed present.

A general regression occurred after the Eocene transgressive episode, and the detrital material accumulated on the continent during the preceding period was released to the basins (Millot, 1964). This event is very well recorded at Site 367 in Core 6, in which sediments are characterized by the association of quartz, feldspars, and kaolinite. This material was probably deposited below the CCD, as suggested by the lack of calcite.

Post-Eocene nannofossil marl and silty clay, documented only by two samples in the study, are characterized by the occurrence of calcite and chlorite. The 
TABLE 6 - Continued

\begin{tabular}{|c|c|c|c|c|c|c|}
\hline Illite & $\begin{array}{c}\text { Mixed } \\
\text { Layer }\end{array}$ & $\begin{array}{l}\text { Smec- } \\
\text { tite }\end{array}$ & $\begin{array}{l}\text { Atta- } \\
\text { pulgite }\end{array}$ & Chlorite & $\begin{array}{c}\text { Kaoli- } \\
\text { nite }\end{array}$ & Total \\
\hline
\end{tabular}

\begin{tabular}{cccccccc}
\hline & & & & & & & \\
2.9 & 3.7 & 2.2 & - & 1.7 & 1.8 & 82 & 18 \\
1.9 & 4.9 & 5.1 & - & 0.8 & 2.7 & 78 & 22 \\
- & 3.6 & 3.8 & - & 0.5 & 1.5 & 76 & 24 \\
1.4 & 4.3 & 3.9 & 0.6 & 1.2 & 1.9 & 80 & 20 \\
0.7 & 3.5 & 7.6 & T & 0.7 & 1.4 & 72 & 28 \\
1.4 & 5.6 & 9.6 & 2.1 & - & 2.2 & 66 & 34 \\
1.4 & 3.2 & 8.8 & 1.8 & T & 3.5 & 66 & 34 \\
1.4 & 4.9 & 15 & - & - & 4.3 & 71 & 29 \\
2.0 & 3.0 & 29 & - & - & 4.1 & 77 & 23 \\
1.5 & 3.2 & 19 & - & - & 5.3 & 84 & 16 \\
2.1 & 3.8 & 13 & - & - & 6.5 & 76 & 24 \\
- & 2.4 & 11 & - & - & 4.9 & 55 & 45 \\
T & 2.0 & 11 & - & - & 6.5 & 44 & 56 \\
T & 1.7 & 16 & - & - & 6.3 & 54 & 46 \\
0.7 & 2.8 & 2.7 & - & - & 3.8 & 80 & 20 \\
0.9 & 2.4 & 4.9 & - & - & 2.4 & 82 & 18 \\
2.4 & 4.0 & 12 & - & - & 5.3 & 59 & 41 \\
2.9 & 1.3 & 15 & - & - & 9.5 & 63 & 37 \\
1.8 & 1.8 & 16 & - & - & 6.9 & 70 & 30 \\
1.0 & 2.3 & 16 & - & - & 6.3 & 64 & 36 \\
2.9 & 1.8 & 14 & - & - & 5.3 & 71 & 29 \\
2.5 & 2.7 & 16 & - & - & 7.2 & 71 & 29 \\
1.3 & 3.9 & 14 & - & - & 7.8 & 72 & 28 \\
0.8 & 2.3 & 13 & - & - & 6.7 & 69 & 31 \\
T & 3.8 & 10 & - & - & 6.0 & 72 & 28 \\
1.4 & 3.2 & 24 & - & - & 6.5 & 64 & 36 \\
T & 2.2 & 19 & - & - & 3.9 & 70 & 30 \\
2.1 & 3.9 & 9.7 & - & - & 3.4 & 76 & 24 \\
T & 3.7 & 17 & - & - & 2.8 & 71 & 29 \\
1.6 & 2.7 & 5.3 & 1.7 & - & T & 67 & 33 \\
- & 1.9 & 7.2 & - & - & - & 96 & 4 \\
- & - & 1.5 & 1.3 & - & - & 92 & 8 \\
- & - & 3.9 & - & - & - & 86 & 14 \\
- & 1.6 & 2.5 & 1.4 & - & - & 91 & 9 \\
- & 0.9 & 4.7 & - & - & - & 96 & 4 \\
- & 1.2 & 5.7 & - & - & - & 96 & 4 \\
T & 1.1 & 1.5 & 1.1 & - & - & 93 & 7 \\
1.2 & 2.1 & 3.2 & 1.5 & - & - & 94 & 6 \\
2.0 & 2.6 & 2.7 & 3.6 & 0.4 & - & 89 & 11 \\
1.5 & 2.0 & 2.3 & 2.3 & - & - & 90 & 10 \\
2.8 & 9.1 & 6.7 & 23 & 2.0 & 1.9 & 80 & 20 \\
- & 1.0 & 1.9 & 2.2 & - & - & 82 & 18 \\
0.7 & 1.1 & 2.7 & 1.9 & 0.3 & - & 93 & 7 \\
2.5 & 3.9 & 6.5 & 14 & 2.6 & - & 78 & 22 \\
0.7 & 2.0 & 1.7 & 2.6 & - & - & 90 & 10 \\
3.9 & 7.2 & 2.5 & 14 & 1.8 & 0.9 & 96 & 4 \\
\hline & & & & & & &
\end{tabular}

occurrence of calcite may indicate a notable increase in the biologic carbonate productivity that depressed the CCD to the floor of the basin. The exact timing of such an event cannot be determined at this site because of widely spaced sampling. The occurrence of chlorite may indicate an active erosion of the continental landmasses.

\section{Site 368-Cape Verde Rise}

Site 368 is located on the southwestern flank of the Cape Verde Rise, about $500 \mathrm{~km}$ off the African coast, in 3367 meters of water. The hole bottomed in Upper Cretaceous black shale after penetrating a diabase sill about 20 meters thick. Fifty-four samples submitted for $\mathrm{X}$-ray analysis (Table 4) allow the establishment of a well-documented mineralogical log (Figure 4). The following mineralogical facies occur, from the bottom to the top of the section.

\section{Core 63 to Core 50}

A "classical" terrigenous assemblage consisting of quartz ( $20 \%$ to $40 \%$ ), feldspars (up to $10 \%$ ), and clay minerals (illite and/or smectite + mixed-layer up to $40 \%$ ) was deposited below the CCD, as indicated by the total lack of calcite. The material in the lower part of this section (Cores 63 to 58) was deposited in a restricted environment, as suggested by the occurrence of pyrite and gypsum; a very similar facies (black shale) occurs at Site 367 in the Cenomanian. The intrusion of the diabase sill, at the scale of our observation controlled by sample spacing, does not seem to have intensely modified the mineralogy of the black shales, 
TABLE 7

Bulk X-Ray Mineralogy Data, Site 370

\begin{tabular}{|c|c|c|c|c|c|c|c|c|c|c|c|c|c|c|}
\hline \multirow[b]{2}{*}{$\begin{array}{c}\text { Sample } \\
\text { (Interval in } \mathrm{cm} \text { ) }\end{array}$} & \multicolumn{2}{|c|}{ Quartz } & \multicolumn{2}{|c|}{ Feldspar } & \multicolumn{2}{|c|}{ Opal-CT } & \multicolumn{2}{|c|}{$\begin{array}{l}\text { Slinoptilo- } \\
\text { lite }\end{array}$} & \multirow[t]{2}{*}{ Calcite } & \multicolumn{2}{|c|}{ Dolomite } & \multirow[t]{2}{*}{ Halite } & \multirow[t]{2}{*}{ Gypsum } & \multirow[t]{2}{*}{ Pyrite } \\
\hline & $\%$ & $\begin{array}{c}\mathrm{L}^{1 / 2} \\
(101)\end{array}$ & Plag. & $\mathrm{K}$ & $\%$ & $\frac{B}{A}$ & $\%$ & $\frac{(200)}{(020)}$ & & $\%$ & Nature & & & \\
\hline $1-3,85-86$ & 10 & 1.7 & 2.1 & 0.7 & - & & - & & 41 & 3.9 & $\mathrm{~S} / \mathrm{C}$ & 0.6 & - & - \\
\hline $2-2,71-72$ & 17 & 1.7 & 3.8 & 0.7 & - & & - & & 18 & 20 & $\mathrm{C} 55+\mathrm{S}$ & 0.4 & - & - \\
\hline $3-1,68-69$ & 19 & 1.7 & 2.6 & 0.8 & - & & - & & 19 & 8.2 & S/C55 & 0.6 & - & - \\
\hline $3-1,105-105$ & 4.8 & & 0.6 & 0.6 & - & & - & & 56 & 2.9 & $\mathrm{~S}+\mathrm{C}$ & 0.7 & - & - \\
\hline $4-3,49-50$ & 26 & 1.7 & 3.6 & 0.5 & - & & - & & 15 & 9.7 & $\mathrm{~S}+\mathrm{C} 55$ & 0.6 & 1.6 & 1.2 \\
\hline $5-3,50-51$ & 26 & 1.7 & 4.1 & 1.4 & - & & - & & 1.0 & 15 & $\mathrm{~S}+\mathrm{C} 55$ & 0.5 & - & 1.2 \\
\hline $5-3,87-88$ & 20 & 1.8 & 2.4 & 0.4 & - & & - & & 12 & 9.9 & $\mathrm{~S}+\mathrm{C} 55$ & 0.3 & 1.6 & 1.4 \\
\hline $6-2,72-73$ & 15 & 1.7 & 2.0 & 0.6 & 18 & 0.58 & - & & 3.6 & 3.0 & $\mathrm{C} 54 / \mathrm{S}$ & - & - & - \\
\hline $8-2,81-82$ & 33 & 1.6 & 4.8 & 1.6 & 22 & 0.56 & - & & 11 & 8.2 & $\mathrm{C} 55 / \mathrm{S}$ & - & 1.1 & 1.9 \\
\hline $9-1,120-121$ & 15 & 1.6 & 1.9 & 1.2 & 31 & 0.56 & - & & 5.4 & 6.3 & $\mathrm{C} 55+\mathrm{S}$ & 0.2 & 0.2 & 0.2 \\
\hline $9, \mathrm{CC}$ & 4.1 & 1.8 & - & - & 59 & 0.56 & - & & 12 & 2.1 & $\mathrm{C} 55 / \mathrm{S}$ & - & - & 0.8 \\
\hline $10-2,51-52$ & 18 & 1.6 & 1.6 & 1.4 & 25 & 0.57 & 0.6 & 0.25 & 15 & 4.7 & $\mathrm{C} / \mathrm{S}$ & $\mathrm{T}$ & $\mathrm{T}$ & 1.6 \\
\hline $12-1,82-83$ & 27 & 1.6 & 4.5 & 0.5 & 13 & 0.55 & 2.0 & 0.49 & 3.8 & 8.4 & $\mathrm{C} 55 / \mathrm{s}$ & $\mathrm{T}$ & 0.8 & 1.6 \\
\hline $13-2,25-27$ & 26 & 1.7 & 2.8 & 1.3 & 29 & 0.53 & $\mathrm{~T}$ & & 26 & 4.4 & $\mathrm{C} 55 / \mathrm{S}$ & - & - & - \\
\hline $13-2,73-75$ & 14 & 1.7 & 1.9 & 0.4 & 20 & 0.48 & 1.6 & 0.35 & 5.0 & 4.0 & $\mathrm{C} / \mathrm{S}$ & 0.2 & - & 1.5 \\
\hline $13-2,99-101$ & 1.6 & & - & - & - & & - & & 86 & - & & - & - & - \\
\hline $14-1,98-99$ & 17 & 1.7 & 1.8 & 0.4 & 19 & 0.42 & - & & 11 & 9.7 & $\mathrm{C} 55 / \mathrm{S}$ & 0.6 & 0.9 & 1.2 \\
\hline $15-3,120-121$ & 3.4 & & - & - & 14 & 0.42 & 0.8 & 0.42 & 39 & 7.3 & C56 & 0.3 & - & - \\
\hline $16-2,35-36$ & 15 & 1.8 & 0.5 & - & - & & - & & 3.4 & 15 & C55 & 0.4 & - & - \\
\hline $17-2,13-14$ & 9.3 & 1.8 & $\mathrm{~T}$ & - & - & & - & & 10 & 18 & C55 & - & 1.0 & $\mathrm{~T}$ \\
\hline $19-1,88-89$ & 7.5 & 2.2 & - & - & 12 & 0.38 & 1.1 & 0.23 & 32 & 7.6 & $\mathrm{C} 55 / \mathrm{s}$ & $\mathrm{T}$ & - & - \\
\hline $20-2,72-73$ & 8.0 & 1.8 & $\mathrm{~T}$ & $\mathrm{~T}$ & - & & - & & 9.0 & 2.9 & C55 & - & - & $\mathrm{T}$ \\
\hline $21-2,26-27$ & 7.2 & 1.8 & $\mathrm{~T}$ & $\mathrm{~T}$ & - & & - & & 10 & 5.4 & C56 & $\mathrm{T}$ & - & $\mathrm{T}$ \\
\hline $22-3,52-53$ & 8.1 & 1.9 & $\mathrm{~T}$ & $\mathrm{~T}$ & - & & - & & 7.8 & 5.3 & $\mathrm{C} 56$ & - & 1.4 & $\mathrm{~T}$ \\
\hline $23-3,82-83$ & 12 & 1.7 & 0.8 & 0.9 & - & & - & & 4.7 & 6.3 & C56 & - & - & - \\
\hline $24-3,82-83$ & 8.4 & 1.9 & $\mathrm{~T}$ & $\mathrm{~T}$ & - & & - & & 16 & 5.2 & $\mathrm{C} 56$ & - & - & - \\
\hline $25-2,62-63$ & 12 & 1.8 & $\mathrm{~T}$ & $\mathrm{~T}$ & - & & - & & 4.8 & 3.8 & C56 & - & 0.4 & - \\
\hline $26-3,62-63$ & 35 & 1.6 & 1.9 & 3.2 & - & & - & & 8.0 & 16 & C56 & - & - & - \\
\hline $27-3,89-90$ & 56 & 1.6 & 5.2 & 8.1 & - & & - & & - & 17 & C56 & 0.7 & - & - \\
\hline $28-3,48-49$ & 25 & 1.6 & 2.2 & 2.0 & - & & - & & 1.2 & 1.3 & C57 & - & 0.3 & - \\
\hline $30-3,67-68$ & 37 & 1.6 & 0.9 & 0.6 & - & & - & & - & - & & - & - & - \\
\hline $31-3,21-22$ & 31 & 1.6 & 1.8 & 2.1 & - & & - & & - & - & & $\mathrm{T}$ & $\mathrm{T}$ & - \\
\hline $32-3,40-42$ & 16 & 1.7 & 0.8 & $\mathrm{~T}$ & - & & - & & 16 & - & & $\mathrm{T}$ & 0.3 & - \\
\hline $34-1,49-50$ & 10 & 1.8 & 0.4 & 0.6 & - & & - & & 81 & 1.1 & $\mathrm{C}+\mathrm{S}$ & - & - & - \\
\hline $34-3,102-103$ & 27 & 1.7 & 3.5 & 2.3 & - & & - & & 15 & 5.5 & $\mathrm{C} 56 / \mathrm{S}$ & - & 0.5 & 8.4 \\
\hline $35-2,72-73$ & 13 & 1.6 & 1.4 & $\mathrm{~T}$ & - & & - & & 32 & 3.0 & C56 & - & $\mathrm{T}$ & 1.9 \\
\hline $38-3,61-62$ & 16 & 1.6 & 1.2 & $\mathrm{~T}$ & - & & - & & 17 & $\mathrm{~T}$ & & - & - & 1.5 \\
\hline $39-4,34-35$ & 15 & 1.7 & 1.7 & $\mathrm{~T}$ & - & & - & & 9.2 & - & & - & - & 2.4 \\
\hline $41-2,35-36$ & 38 & 1.6 & 4.3 & 2.1 & - & & - & & 19 & - & & - & - & - \\
\hline $42-3,115-116$ & 24 & 1.6 & 2.5 & 0.7 & - & & - & & 9.7 & - & & - & - & - \\
\hline $42-4,32-33$ & 10 & 1.7 & 1.6 & 0.4 & - & & - & & 25 & - & & - & - & - \\
\hline $42-4,39-40$ & 20 & 1.7 & 1.7 & $\mathrm{~T}$ & - & & - & & 1.7 & - & & - & - & - \\
\hline $43-2,28-29$ & 46 & 1.6 & 11 & 4.1 & - & & - & & 20 & 1.4 & $\mathrm{C}$ & - & - & - \\
\hline $44-3,68-69$ & 49 & 1.6 & 7.7 & 2.5 & - & & - & & 5.5 & 1.7 & $\mathrm{C}$ & - & - & - \\
\hline $45-3,118-119$ & 47 & 1.6 & 5.7 & 3.9 & - & & - & & 2.5 & $\mathrm{~T}$ & C & - & - & - \\
\hline $47-3,141-142$ & 58 & 1.6 & 9.8 & 4.8 & - & & - & & 16 & $\mathrm{~T}$ & C & - & - & - \\
\hline $51-2,146-147$ & 41 & 1.6 & 7.9 & 2.4 & - & & - & & 35 & - & & - & - & - \\
\hline
\end{tabular}

except in the immediate vicinity (Core 60) where smectite and mixed-layer clays collapsed to illitic structure upon heating. Attapulgite occurs in minor amounts in the upper part of the interval (Cores 56 to 50 ), whereas quartz is slightly chalcedonic. This mineralogical association probably indicates a moderate transgressive episode, as it will be seem further in the Tertiary section. Kaolinite replaces attapulgite in the upper part of the interval, indicating a probable moderate regressive episode. The amounts of amorphous material range from $30 \%$ to $50 \%$. These features suggest minor changes in the nature of the sources of the terrigenous material.

\section{Core 47 to 18}

The dominant feature of this thick section is the occurrence of considerable amounts of attapulgite and sepiolite, constituting up to $80 \%$ of the sediments which were deposited by turbidity currents (see Site Chapter). Sepiolite occurs mainly in the lower part of the interval. Again the origin of these magnesium-rich fibrous clay minerals must be related to a "sédimentation chimique basique" (Millot, 1964, p. 308-320), within basins such as the Senegal Basin where the thickness of the attapulgite + sepiolite deposits reaches 500 meters for the upper Paleocene and the lower Eocene intervals. Large amounts of attapulgite and sepiolite could be expected in the deep basin turbidites because of the geographic location of Site 368 in front of the Senegal Basin, widely open on the Atlantic Ocean. The thickness of the attapulgite + sepiolite sequence reaches 350 meters, whereas at Site 367 the same episode was recorded in only 100 meters of sediment and the cumulated amounts of both minerals averaged 
TABLE 7 - Continued

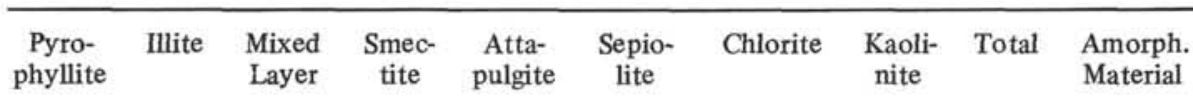

\begin{tabular}{|c|c|c|c|c|c|c|c|c|c|}
\hline- & 17 & 3.0 & 3.0 & - & - & 6.0 & 1.0 & 88 & 12 \\
\hline- & 8.0 & 5.5 & 3.5 & 5.0 & - & 5.0 & $\mathrm{~T}$ & 87 & 13 \\
\hline- & 14 & 4.5 & 5.0 & 10 & - & 5.0 & $\mathrm{~T}$ & 79 & 21 \\
\hline- & 3.5 & 3.1 & 2.6 & 1.3 & - & 1.5 & $\mathrm{~T}$ & 78 & 22 \\
\hline- & 9.0 & 4.6 & 3.3 & 2.7 & - & 2.6 & $\mathrm{~T}$ & 80 & 20 \\
\hline - & 7.0 & 4.2 & 16 & 2.8 & - & 2.0 & 0.5 & 82 & 18 \\
\hline- & 12 & 5.5 & 4.7 & 3.0 & - & 2.0 & 0.8 & 76 & 24 \\
\hline - & 5.0 & 4.0 & 12 & 6.2 & - & 1.3 & $\mathrm{~T}$ & 72 & 28 \\
\hline- & 2.2 & 3.1 & 1.7 & 1.9 & - & 1.1 & - & 94 & 6 \\
\hline- & 2.1 & 3.8 & 2.8 & 8.0 & - & 1.2 & - & 80 & 20 \\
\hline- & $\mathrm{T}$ & 1.5 & 1.0 & 5.1 & - & - & - & 86 & 14 \\
\hline- & 1.3 & 2.8 & 7.4 & 5.5 & - & - & - & 85 & 15 \\
\hline- & 3.2 & 2.3 & 6.5 & 6.6 & - & 1.2 & - & 81 & 19 \\
\hline- & - & - & 4.2 & 1.5 & - & - & - & 95 & 5 \\
\hline- & 2.3 & 4.0 & 7.0 & 13 & 1.3 & 1.1 & - & 78 & 22 \\
\hline- & - & 0.8 & 1.2 & 1.0 & - & - & - & 91 & 9 \\
\hline- & 2.7 & 3.0 & 2.7 & 16 & - & 0.7 & - & 88 & 12 \\
\hline- & 1.0 & 1.8 & 1.9 & 11 & $\mathrm{~T}$ & $\mathrm{~T}$ & - & 80 & 20 \\
\hline- & 2.4 & 5.5 & 7.3 & 29 & 7.4 & 2.0 & - & 88 & 12 \\
\hline- & 3.0 & 4.0 & 5.4 & 18 & 7.0 & 1.7 & - & 78 & 22 \\
\hline- & 3.2 & 1.7 & 15 & 4.8 & 2.1 & 0.9 & - & 88 & 12 \\
\hline- & $\mathrm{T}$ & $\mathrm{T}$ & 62 & 6.0 & - & $\mathrm{T}$ & 7.3 & 95 & 5 \\
\hline- & $\mathrm{T}$ & $\mathrm{T}$ & 33 & 12 & - & $T$ & 5.0 & 73 & 27 \\
\hline- & 1.5 & 1.0 & 26 & 13 & - & $T$ & 3.1 & 69 & 31 \\
\hline- & - & 2.5 & 48 & - & - & - & 9.2 & 83 & 17 \\
\hline- & 2.0 & 1.3 & 42 & - & - & - & 11 & 86 & 14 \\
\hline- & 2.0 & 2.0 & 61 & - & - & - & 6.9 & 93 & 7 \\
\hline- & 3.5 & 1.7 & 22 & - & - & $\mathrm{T}$ & 4.4 & 96 & 4 \\
\hline- & 0.4 & 2.4 & 1.9 & 8.9 & - & 0.9 & - & 95 & 5 \\
\hline- & 3.0 & 9.0 & 2.0 & 28 & - & 1.0 & 1.0 & 77 & 23 \\
\hline 0.6 & 5.1 & 8.5 & 3.0 & 10 & - & 3.0 & 2.6 & 72 & 28 \\
\hline 0.6 & 9.0 & 11 & 3.0 & 8.0 & - & 1.0 & 3.1 & 71 & 29 \\
\hline 1.2 & 9.0 & 8.6 & 3.3 & 7.0 & - & 2.3 & 2.3 & 67 & 33 \\
\hline- & - & - & - & $\mathrm{T}$ & - & - & - & 94 & 6 \\
\hline 0.6 & 5.6 & 6.3 & 1.1 & 5.2 & - & 2.3 & 2.3 & 86 & 14 \\
\hline 0.7 & 10 & 8.2 & 2.2 & 5.0 & - & 3.0 & 4.2 & 85 & 15 \\
\hline 1.4 & 20 & 14 & 2.3 & - & - & 5.0 & 9.2 & 88 & 12 \\
\hline 0.6 & 25 & 20 & 1.5 & - & - & 8.0 & 10 & 94 & 6 \\
\hline 1.9 & 9.0 & 7.0 & 2.6 & - & - & 3.1 & 4.0 & 86 & 14 \\
\hline 1.0 & 15 & 13 & 3.0 & - & - & 4.2 & 7.8 & 81 & 19 \\
\hline 0.7 & 15 & 11 & 5.0 & - & - & 3.0 & 9.1 & 81 & 19 \\
\hline $\mathrm{T}$ & 21 & 15 & 4.7 & - & - & 4.1 & 14 & 82 & 18 \\
\hline 0.7 & 6.3 & 0.7 & 1.3 & - & - & 2.6 & 1.1 & 95 & 5 \\
\hline 1.4 & 14 & 2.0 & 1.2 & - & - & 3.9 & 3.9 & 93 & 7 \\
\hline 2.4 & 11 & 3.0 & 2.6 & - & - & 4.2 & 6.9 & 89 & 11 \\
\hline $\mathrm{T}$ & 3.3 & 2.4 & $\mathrm{~T}$ & - & - & 1.0 & 1.0 & 96 & 4 \\
\hline- & 5.4 & - & 1.3 & - & - & 2.2 & 1.1 & 96 & 4 \\
\hline
\end{tabular}

only $40 \%$ of the sediment (see preceding paragraph, "Site 367"). The episode was also recorded at Site 366, but very weakly (maximum of attapulgite amount: $4 \%$ ). Site 368 appears to be in a relatively proximal position in the spreading of these magnesium-rich clay minerals from the Senegal Basin. Site 366 is in a very distal position and Site 367 is located in an intermediate position.

The thick attapulgite + sepiolite sequence at Site 368 was deposited in a deep basinal environment, below the $\mathrm{CCD}$, as suggested by the total lack of clacite (dilution, even by huge masses of terrigenous material, would not have completely masked the biogenic carbonate supply). This deep basinal position of Site 368 during the attapulgite + sepiolite episode conflicts with its present position on a rise, suggesting that the Cape Verde Rise did not exist at the time.

Because the attapulgite + sepiolite episode is known onshore to be restricted to the upper Paleocene and the lower Eocene (Ypresian), it constitutes a good stratigraphic marker, and may be of valuable help in stratigraphic refinement of Site 368 sedimentary section. The first notable occurrence of both minerals at Site 368 (Core 47) should not be older than upper Paleocene. The end of the episode of redeposition, however, which accounts for the occurrence of attapulgite and sepiolite in the surrounding oceanic basins, is not necessarily synchronous everywhere.

The lack of a "classical" terrigenous mineral assemblage (quartz, feldspars, kaolinite), is the result of the 


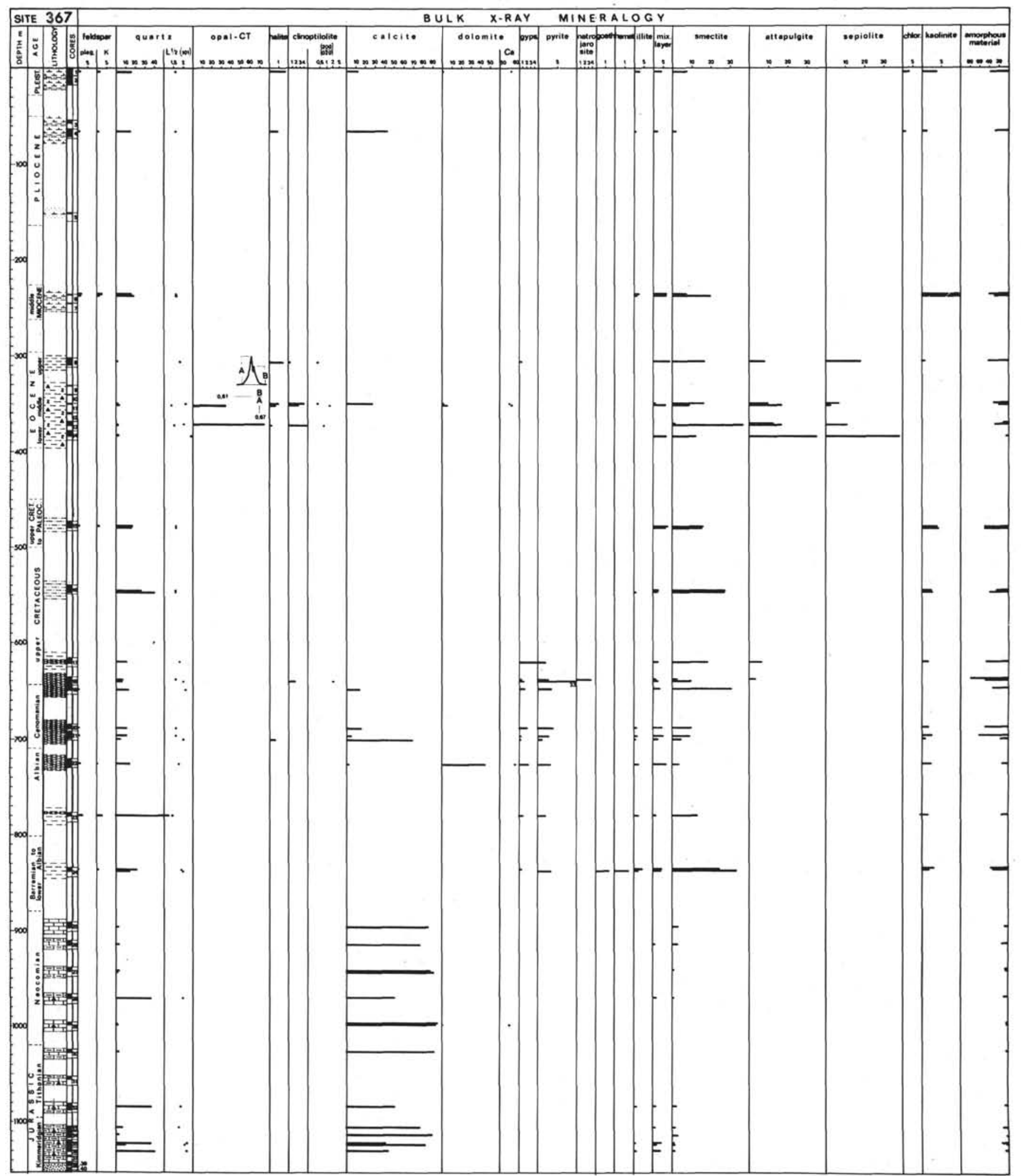

Figure 3. Bulk X-ray mineralogy data, Site 367.

attapulgite + sepiolite episode being related to a transgressive episode onshore (Millot, 1964), during which the continental sources did not supply any detrital material.

Dolomite occurs sporadically in various amounts throughout this section. The occurrence of stoichio- metric dolomite (a recrystallized form) is restricted to the base of the section (Cores 41 to 38), and correlates with a maximum of the attapulgite + sepiolite input, which suggests a probable allochthonous origin for this mineral. Dolomite occurs as a slightly calcic form in the upper part of the section, which suggests a possible 


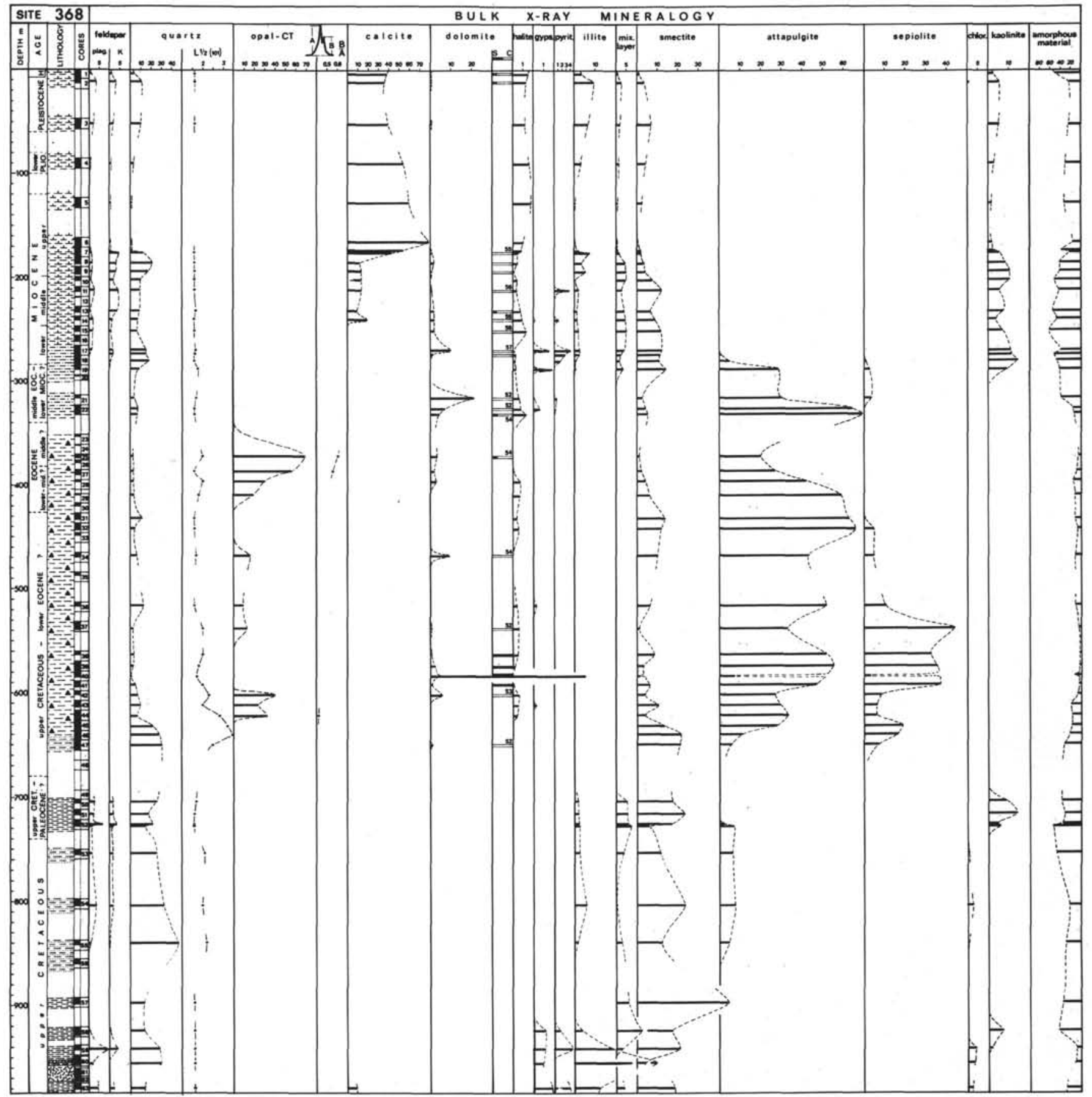

Figure 4. Bulk X-ray mineralogy data, Site 368.

authigenic origin. In such a case, the source of calcium may have been biogenic calcite, either crossing the CCD because of an increase of the supply, or reaching the sea floor as a result of a sporadic drop of the CCD.

Crystalline silica occurs throughout the attapulgite + sepiolite episode, either as opal-CT or as chalcedony. The B/A ratio in opal-CT decreases downward from 0.6 to 0.4 , and chalcedony has lower values than opalCT. Such a downward trend is encountered, and much better documented, at Site 366. This suggests that the evolution of silica, from amorphous biogenic remains to mature cherts, is probably not related to local conditions, but is controlled by factors depending on burial depth, in addition to lithological factors that could be related to paleoenvironmental conditions.

The co-occurrence of magnesium-rich clay minerals and opal-CT, already encountered at both Sites 366 and 367 , poses a problem of paleoenvironment which cannot be discussed here on the basis of the mineralogical data only. The solution to this problem is probably best approached in terms of paleoclimatology, because the attapulgite + sepiolite episode is probably related to a transgression on the stable African craton. 


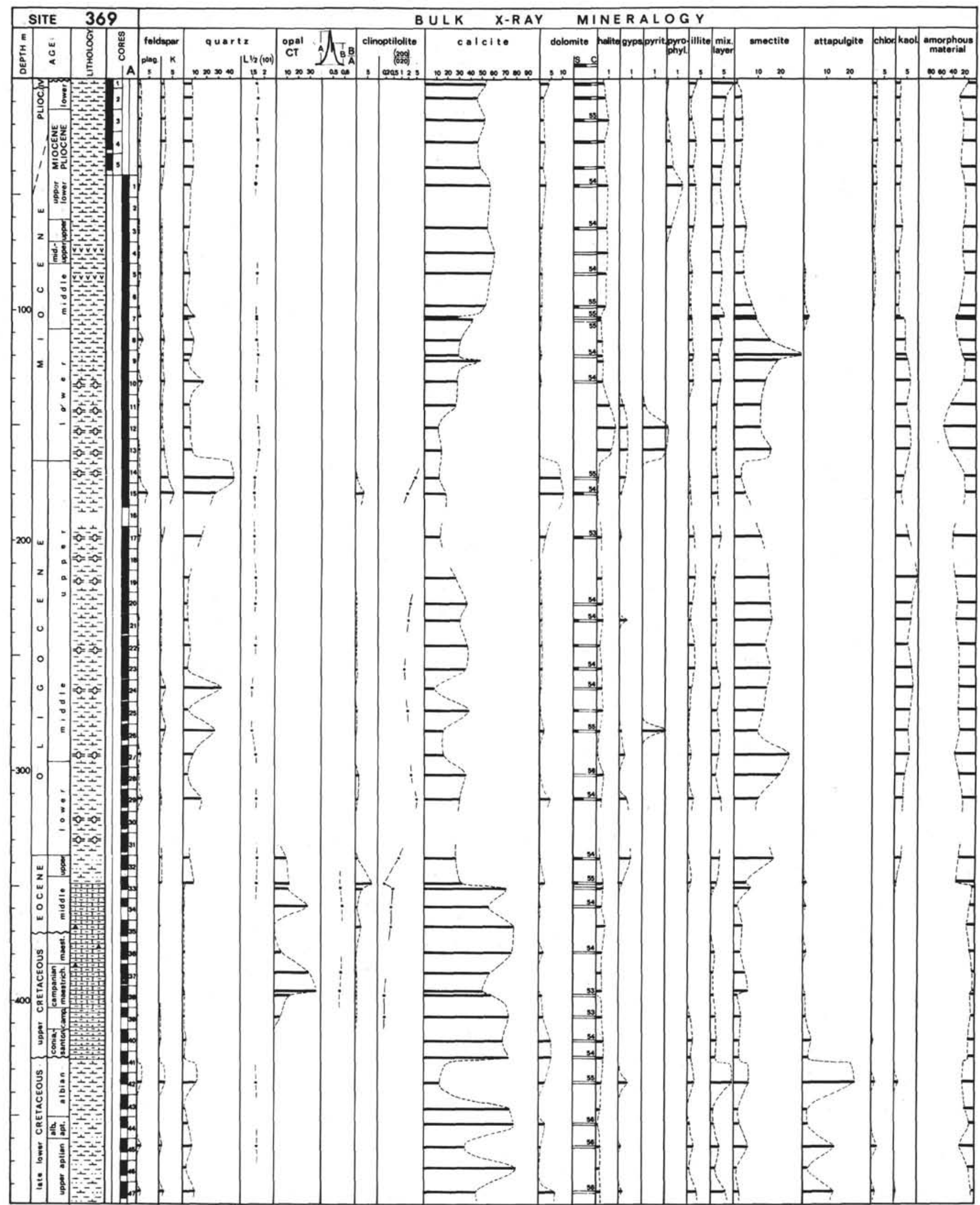

Figure 5. Bulk X-ray mineralogy data, Site 369. 


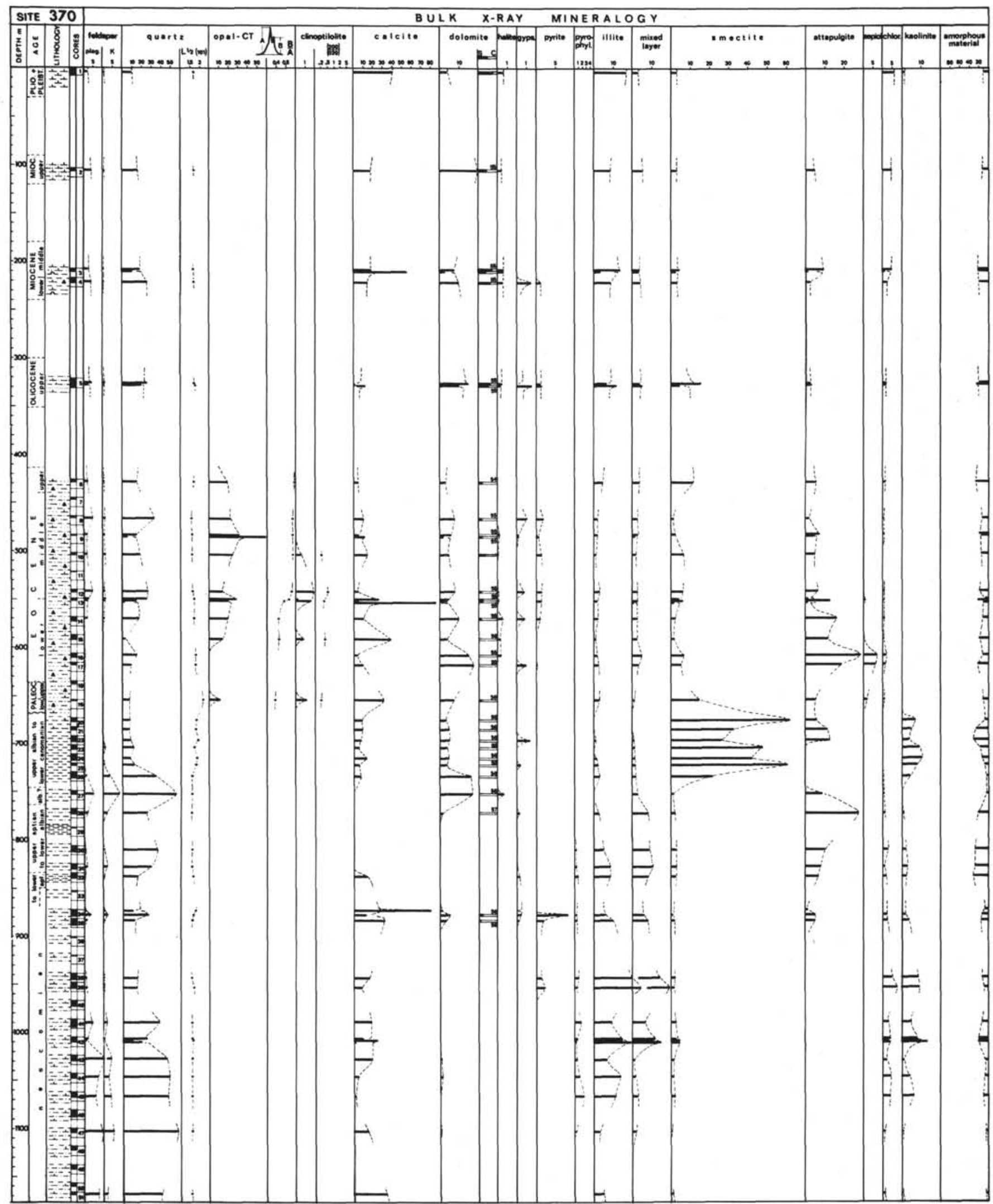

Figure 6. Bulk X-ray mineralogy data, Site 370. 


\section{Core 17 to Core 7}

Sediments from this interval consist mainly of quartz, feldspars, kaolinite, illite and illite-derived clays, and large amounts of amorphous material. This terrigenous material, accumulated on the continent during the preceding transgressive episode, was redeposited as a result of a general regression (Millot, 1964). The transition from the former to the latter facies is gradual and is recorded in Cores 19, 18, and 17.

Small but constant amounts of calcite $(10 \%$ of the sediment) occur throughout the section, and are interpreted as a lowering of the CCD rather than an uplift of the area because the terrigenous components would have hardly reached an uplifted location. The calcite was completely dolomitized through diagenesis at the base of the section (Core 17 to Core 15), as indicated by the very high calcium content of the dolomite (compared to the lesser calcium content of the underlying dolomite), and the absence of stoichiometric dolomite. This dolomitization is probably related to the high magnesium content of the thick underlying sequence and was favored by restricted depositional conditions (occurrence of pyrite). A slight dolomitization of calcite occurred throughout this section.

\section{Core 6 to Core 1}

The mineralogical spectrum of the sediments in these cores is characterized by large amounts of calcite, reaching almost $80 \%$ at the base and decreasing progressively upward to $40 \%$. The nature of the terrigenous input remains exactly the same as that of the underlying section, but its amount drops abruptly. These features strongly suggest that a notable change in the physiographic position of Site 368 occurred at the time when the sediments of Core 7 were deposited (early upper Miocene; 8 m.y. B.P.). This change must be the uplift of the Cape Verde Rise, which raised the sea floor to a high position away from the path of the turbidity currents and above the CCD. A drop of the CCD is unlikely to account for this change in the sedimentation, because, in such a case, the input of terrigenous material could not have been reduced so abruptly and in such porportion.

The progressive increase in the amounts of terrigenous constituents during the Pliocene and the Pleistocene, which resulted in the decrease of the calcite content of the sediments, is related to active erosion and sedimentation processes well documented in the Atlantic basins.

\section{Site 369-Continental Slope off Spanish Sahara}

Site 369 is located on the Continental Slope off Cape Bojador, about $70 \mathrm{~km}$ off the African coast, in 1760 meters of water. The section was continuously cored down to 388.5 meters, reaching upper Aptian sediments. Fifty-one samples were submitted for X-ray analysis (Tables 5 and 6; Figure 5). The mineralogical assemblages do not show major changes in their nature but the units, defined on the basis of the lithology, differ in the respective amounts of each constituent.

Upper Aptian to Albian dark silty nannofossil marl is characterized by large fluctuations in the relative amounts of twc opposing constituents: (1) terrigenous material, which consists of quartz, feldspars (Kfledspar and plagioclase), clay minerals (attapulgite dominant, illite, mixed-layer, smectite, and chlorite), and amorphous material; and (2) calcite, which constitutes at times up to $80 \%$ of the sediment. This opposition suggests a biogenic origin for the calcite. Minor amounts of calcium-rich dolomite occur just above the peaks of attapulgite and because the calcium content of this mineral decreases upward, dolomite here is probably authigenic.

Upper Cretaceous marly limestone and chalk consists of very abundant calcite and lesser amounts of opal-CT. The content of terrigenous material is very low (less than $10 \%$ ), and this material consists of minor amounts of smectite and mixed-layer clays, and traces of quartz and attapulgite. The content of amorphous material is the lowest encountered in this work.

Sediments in this section are strongly lithified through recrystallization. Such an intense recrystallization probably occurred because of the very low content of terrigenous material; it affected both calcareous tests and siliceous remains, which have been the source for calcitic cement and opal-CT, respectively. The high $\mathrm{B} / \mathrm{A}$ ratio of the opal-CT indicates that this mineral is immature, possibly because of an insufficient burial depth. This immaturity of opal-CT is consistent with the lack of chalcedony.

Clinoptilolite occurs in minor amounts. It is of the "normal" type, as indicated by its low $(200) /(020)$ peak-height ratio (see "Comments on Mineralogical Data").

Upper Eocene to lower Miocene siliceous nannofossil marl is characterized by a notable content of terrigenous material, averaging $40 \%$ of the sediment (highest average value at this site), a high content of amorphous material (average value: $30 \%$ ), and a relatively moderate content of calcite (average value) $30 \%$ ). The terrigenous material consists mainly of clay minerals, having a constant mineralogical spectrum both qualitatively and quantitatively. Smectite dominates, followed by kaolinite and minor amounts of illite and mixed-layer clays. Curves of quartz and feldspar variation show several peaks at the expense of calcite. These features indicate that, by comparison with the other intervals of the sedimentary section, the sedimentation, from the upper Eocene to the lower Miocene, was notably influenced by the input of terrigenous material. This resulted in the deposition of a relatively thick sequence $(220 \mathrm{~m})$ of roughly $50 \%$ of terrigenous and $50 \%$ of biogenic materials.

Dolomite occurs in minor amounts throughout the section and its variations follow that of quartz. Stoichiometric dolomite is subordinate, but almost always present; calcium-rich dolomite is dominant, the calcium content averages $54 \%$. Therefore, dolomite is probably partly allochthonous and partly authigenic.

Clinoptilolite occurs in trace amounts nearly throughout the section; the highest amount occurs in Core 15, together with a notable amount of typical terrigenous material (quartz + feldspars $=40 \%$ ). The $(200) /(020)$ peak-height ratio shows very high values, indicating an "atypical" form (see "Comments on Mineralogical Data"), especially in Core 15. Therefore, 
the $(200) /(020)$ peak-height ratio is tentatively interpreted as an indicator of origin. The high values ("atypical" form) could characterize a "terrigenous" clinoptilolite, whereas the low values ("normal" form) would indicate an authigenic, possibly recrystallized, clinoptilolite. This interpretation seems supported by the occurrence of "normal" clinptilolite in the underlying section (opal-CT zone), where an intense recrystallization has been pointed out. This critical point of polymorphism of clinoptilolite obviously needs further investigation.

Lower Miocene to Quaternary nannofossil marl is characterized by a very constant mineralogical spectrum, dominated by calcite which averages about $50 \%$. The occurrence of chlorite and pyrophyllite (episodic) and the upward increase in the amount of stoichiometric dolomite among the dolomitic phase, suggests some change in the nature of the sources of the terrigenous material, probably related to a moderate tectonic activity on the continent.

\section{Site 370-Deep Basin off Morocco}

Site 370 is located at the base of the Continental Rise off Cape Santin, Morocco, in 4216 meters of water. The sedimentary section was cored discontinuously in the upper third, and semicontinuously down to 1176.5 meters, eventually reaching lower Neocomian sediments. Forty-seven samples were submitted for X-ray analysis (Table 7; Figure 6). The sedimentary section is divided into three main intervals on the basis of the mineralogical associations.

Neocomian to Lower Cenomanian Calcareous Silty Claystones

This interval is characterized by very high amounts of terrigenous material, constituting up to $80 \%$ of the sediment, with the content of quartz averaging $40 \%$. Plagioclase is the most abundant feldspar from Core 51 to Core 41. Clay minerals consist mainly of illite and illite-derived mixed-layer clays, followed by kaolinite and chlorite, but smectite occurs only in trace amounts. This association suggests an active erosion of a landmass and a rapid sedimentation of immature detrital terrigenous material.

The content of quartz + feldspar in Cores 39 and 38 decreases whereas the illitic material increases markedly. This indicates a reduction of the transportation processes, possibly related to a slight transgression.

The K-feldspar becomes progressively the most abundant feldspar from Core 35 to Core 25, suggesting that the terrigenous material has undergone a long evolution (maturation) onshore before it settled in the deep basin. This may indicate a progressive flattening of the continental landmasses, through continuous erosion. The occurrence of attapulgite from Cores 35 through 27 seems to support this hypothesis. This mineral was probably generated in continental basins through chemical sedimentation during transgressive episodes.

The occurrence of considerable amounts of smectite together with kaolinite in the upper part of the section (Cores 26 through 20) indicates a regressive episode during which the products of strongly weathered rocks were delivered to the basin.
Calcite occurs throughout the section in minor to moderate amounts. This occurrence suggests either that Site 370 remained slightly above the CCD during this period, or that most of the calcareous material is redeposited. In the former case, a rise of the CCD level would have occurred during the transgressive episode (attapulgite), preventing any deposition of carbonate. Alternatively, this could correspond to a decrease in the amounts of redeposited carbonates being delivered into the deep part of the basin. Dolomite occurs mainly in the upper part of the interval only as the calcium-rich type with very constant calcium contents. This mineral is probably of terrigenous origin because it correlates well with quartz + feldspar input.

\section{Lower Paleocene to Upper Eocene Calcareous and Siliceous Silty Clay}

This interval is characterized by the occurrence of opal-CT and clinoptilolite. Opal-CT constitutes about $30 \%$ of the sediment. The value of its B/A ratio (see "Comments on Mineralogical Data") is high and constant in the upper part of the interval, decreases suddenly at 550 meters sub-bottom, and remains low down to the base of the interval. This abrupt transition from immature to mature opal-CT contrasts with the progressive transition at Site 366 . No major change in the mineralogical facies of the sediment, except a slight downward decrease in the quartz + feldspar content, can account for this change. Nevertheless, the evolution of opal-CT from immature to mature forms, occurs here with depth in a manner similar to what has been observed at the other sites. A comparison of the depth of maturation at different sites shows that: (1) above 400 meters (Sites 367,368 , and 369), opal-CT is always immature (high $\mathrm{B} / \mathrm{A}$ ratio value); and (2) below 600 meters, opal-CT is mature (low B/A ratio value, Sites 368 and 370 ) or near-mature (Site 366). The transformation occurs gradually (Site 366 ) or abruptly (Site 370 ), but always in the range of $400-600$ meters. Therefore, the depth of burial (temperature ?, pressure ?, age ?) appears to be a critical parameter of the evolution of opal-CT.

Clinoptilolite occurs in minor amounts. Its $(200) /(020)$ peak height ratio has a low value (normal type), indicating that this mineral is probably authigenic (see "Site 369").

The base of the interval is marked by the occurrence of sepiolite which, together with a maximum of attapulgite, marks the Paleocene to lower Eocene transgressive episode (see "Site 368").

The amounts of terrigenous material do not change markedly within this interval, except for a decrease in the content of quartz + feldspar in the lower part, in relation to the attapulgite + sepiolite transgressive episode. Plagioclase is the prominent feldspar which suggests an immature nature for the terrigenous material, the result of a rather active erosion of the landmasses.

Calcite occurs in small to moderate amounts, as in the underlying interval, and its occurrences can be interpreted in the same manner. Dolomite content is noticeable, but does not show any significant correlation with other minerals. Stoichiometric dolomite occurs in the upper part of the interval but remains subordinate. 


\section{Post Eocene Sediments}

This interval is poorly documented and the mineralogical spectrum does not change significantly. Contents of illite and chlorite increase very slightly upward, whereas quartz content follows the opposite trend. Dolomite occurs in notable amounts and, relative to the underlying interval, stoichiometric dolomite becomes prominent. Calcite content increases progressively upward and constitutes up to $40 \%$ of the Pleistocene nannofossil marl. These features may indicate that the basin was progressively filled with terrigenous material becoming finer and finer, which implies a transition to more pelagic conditions.

\section{ACKNOWLEDGMENTS}

The author wishes to thank Dr. Yves Lancelot (Centre National de la Recherche Scientifique, France) who critically reviewed the manuscript, and Dr. René Létolle (Université Pierre et Marie Curie, Paris) for helpful discussions and suggestions. Technical assistance was provided by Josiane Granger and Christine Vigne.

\section{REFERENCES}

Biscaye, P.E., 1964. Distinction between kaolinite and chlorite in Recent sediments by X-ray diffraction: Am. Mineralogist, v. 49, p. 1281-1289.

1965. Mineralogy and sedimentation of Recent deep-sea clay in the Atlantic Ocean and adjacent Seas and Oceans: Geol. Soc. Am. Bull., v. 76, p. 803-832.

Borg, I.Y. and Smith, D.K., 1969. Calculated X-ray powder pattern for silicate minerals: Geol. Soc. Am., Mem. 122.

Brown, G., 1963. The X-ray identification and crystal structure of clay minerals: Mineralogical Soc. London.

Deffeyes, K.S., 1959. Zeolites in sedimentary rocks: J. Sediment Petrol., v. 29, p. 602-609.
Goldsmith, J.R. and Graf, D.L., 1958. Relation between lattice constants and composition of the $\mathrm{Ca}-\mathrm{Mg}$ carbonates: Am. Mineralogist, v. 43, p. 84-101.

Hathaway, J.C. and Sachs, P.L., 1965. Sepiolite and clinoptilolite from the Mid-Atlantic Ridge: Am. Mineralogist, v. 50, p. 852-867.

Heath, G.R. and Moberly, R., 1971. Cherts from the Western Pacific, Leg 7, Deep Sea Drilling Project. In Winterer, E.L., Riedel, W.R., et al., Initial Report of the Deep Sea Drilling Project, Volume 7: Washington (U.S. Government Printing Office), p. 991-1007.

Jones, J.B. and Segnit, E.R., 1971. The nature of opal. I. Nomenclature and constituent phases: J. Geol. Soc. Australia, v. 18 , p. 57-68.

Keene, J.B., 1975. Cherts and porcellanites from the North Pacific, DSDP Leg 32. In Larson, R.L., Moberly, R., et al., Initial Reports of the Deep Sea Drilling Project, Volume 32: Washington (U.S. Government Printing Office), p. 429-507.

Klug, H.P. and Alexander, L.E., 1967. X-ray diffraction procedures: New York (John Wiley and Sons, Inc.).

Lancelot, Y., 1973. Chert and silica diagenesis in sediments from the Central Pacific. In Winterer, E.L., Ewing, J.I., et al., Initial Reports of the Deep Sea Drilling Project, Volume 17: Washington (U.S. Government Printing Office), p. $377-405$.

Mélières, F., 1973. Porte-échantillon tournant pour analyse par diffractométrie X: Soc. française Min. Crist. Bull., v. 96, p. $75-79$.

1974. Recherches sur la dynamique sédimentaire du Golfe de Cadix (Espagne): Thèse, Université Pierre et Marie Curie, Paris.

Millot, G., 1964. Géologie des argiles: Paris (Masson et Cie). Mumpton, F.A., 1960. Clinoptilolite redefined: Am. Mineralogist, v. 45 , p. 351.

von Rad, U. and Rösch, H., 1972. Mineralogy and origin of clay minerals, silica and authigenic silicates in Leg 14 sediments. In Hayes, D.E., Pimm, A.C., et al., Initial Report of the Deep Sea Drilling Project, Volume 14: Washington (U.S. Government Printing Office), p. 727751 . 